\title{
Overexpression of MAGEA2 has a prognostic significance and is a potential therapeutic target for patients with lung cancer
}

\author{
HIDEKI UJIIE ${ }^{1}$, TATSUYA KATO ${ }^{1,2}$, DAIYOON LEE ${ }^{1}$, HSIN-PEI HU ${ }^{1}$, KOSUKE FUJINO $^{1}$, \\ MITSUHITO KAJI $^{3}$, KICHIZO KAGA ${ }^{2}$, YOSHIRO MATSUI ${ }^{2}$ and KAZUHIRO YASUFUKU $^{1}$ \\ ${ }^{1}$ Division of Thoracic Surgery, Toronto General Hospital, University Health Network, Toronto, University of Toronto, \\ Ontario, Canada; ${ }^{2}$ Department of Cardiovascular and Thoracic Surgery, Hokkaido University Graduate School of \\ Medicine; ${ }^{3}$ Department of Thoracic Surgery, Sapporo Minami-sanjo Hospital, Sapporo, Hokkaido, Japan
}

Received January 12, 2017; Accepted March 16, 2017

DOI: 10.3892/ijo.2017.3984

\begin{abstract}
Melanoma-associated antigens (MAGE) are expressed in different type of cancers including lung cancer and have been shown to be functionally related to $\mathrm{p} 53$ tumor suppressor gene. Little is known about the relationship between MAGE genes and p53 aberrant expression in lung cancer. The aims of this study were to observe the expression of MAGEA2, examine the role of MAGEA2 in lung cancer survival, investigate its correlation between MAGEA2 and p53, and explore its clinicopathologic significance as a prognostic marker. Quantitative reverse transcription-polymerase chain reaction was performed to detect the expression of MAGEA2 using 36 primary tumors and 31 metastatic lymph nodes from patients with lung cancer. The role of MAGEA2 in cancer cell growth and in the regulation of p53 downstream genes were examined using small interfering RNA. The expression of MAGEA2 and p53 were analyzed immunohistochemically using tissue microarray from 353 resected lung specimens. High-level expression of MAGEA2 (High-MAGEA2) was confirmed in lung tumors with high frequency. Inhibiting MAGEA2 expression effectively suppressed cancer cell growth and decreased the expression of p53 downstream target genes in vitro. In adenocarcinoma, High-MAGEA2 was strongly
\end{abstract}

Correspondence to: Dr Kazuhiro Yasufuku, Division of Thoracic Surgery, Toronto General Hospital, 200 Elizabeth St., 9N-957, Toronto, ON M5G2C4, Canada

E-mail: kazuhiro.yasufuku@uhn.ca

Abbreviations: ADC, adenocarcinoma; EBUS-TBNA, endobronchial ultrasound-guided transbronchial needle aspiration; H\&E, hematoxylin and eosin; HR, hazard ratio; IHC, immunohistochemical; LCC, large cell carcinomas; LN, lymph node; MAGE, melanomaassociated antigens; NSCLC, non-small cell lung cancer; OS, overall survival; qRT-PCR, quantitative reverse transcription-polymerase chain reaction; SCC, small cell lung cancers; siRNA, small interfering RNA; SqCC, squamous cell carcinomas; TMA, tissue microarrays

Key words: biomarker, EBUS-TBNA, lung cancer, MAGEA2, p53, therapeutic target associated with aberrant p53 expression $(\mathrm{P}<0.001)$ and was associated with worse clinical outcomes (5-year OS, $87.1 \%$ in low vs. $74.1 \%$ in high, $\mathrm{P}=0.014)$. Aberrant $\mathrm{p} 53$ expression was also significant worse prognostic factor $(\mathrm{P}=0.029)$. Among the adenocarcinoma patients with wild-type p53, High-MAGEA2 had poorer prognosis than low-level MAGEA2 groups (5-year OS, $90.1 \%$ vs. $72.1 \%, \mathrm{P}=0.037$ ), whereas had no difference in p53 aberrant tumors. On multivariate analysis, MAGEA2 was independently associated with survival (hazard ratio; 2.12, $\mathrm{P}=0.030$ ). In conclusion, suppression of MAGEA2 in lung cancer cells significantly reduced the growth/survival of cancer cells. High-MAGEA2 was identified as an independent prognostic factor in lung adenocarcinoma. Specific inhibition of MAGEA2 may be a promising therapeutic strategy for patients with lung cancer.

\section{Introduction}

Lung cancer is the leading cause of cancer-related mortality worldwide (1). According to the results from the National Lung Screening Trial, an increase in the detection and treatment of early stage lung cancer is expected (2). However, despite curative-intent surgical resection, tumor recurrence and metastasis remain the primary causes of cancer-related death even among patients with early stage lung cancer (3). Furthermore, lung cancer is still usually not detected until it is at an advanced stage, which makes it more challenging to treat due to high frequency of metastasis. The 5-year survival for patients with regional lymph node (LN) metastasis shows poor prognosis $(1,4)$. Inadequacy of major improvements in the survival rate for lung cancer in spite of advances in surgery, chemotherapy, and radiotherapy has driven a search for new strategies aimed at improving lung cancer management and treatment, which requires a better understanding of lung cancer biology. In an effort to identify relevant molecular targets for diagnosis and/or treatment of lung cancer $(5,6)$. We analyzed expression profiles of our previously performed microarray using endobronchial ultrasound-guided transbronchial needle aspiration (EBUS-TBNA) samples (7) and various types of database (8). Confirmatory quantitative reverse transcriptionpolymerase chain reaction (qRT-PCR) analysis was performed against 122 possible candidate genes using tumor samples 
achieved by EBUS-TBNA (8). These genes are i) overexpressed in the majority of EBUS-TBNA samples taken from advanced lung cancer cases, ii) overexpressed in at least one lung cancer cell line for RNAi screening, and iii) expressed most in the testis and less expressed in other human vital organs, which provides further evidence supporting these genes as promising molecular targets.

Throughout these screenings, we selected melanomaassociated antigens (MAGE) family member A2 (MAGEA2) as a possible candidate therapeutic gene of lung cancer. MAGE genes were initially discovered as cancer-associated antigens in melanoma patients (9) and are now known to comprise of a super-family of more than 60 genes in humans $(10,11)$. This family of genes has been shown to be overexpressed in a variety of cancers including non-small cell lung cancer (NSCLC) and rarely expressed in normal human organs, therefore, they are potential biomarkers for early diagnosis and screening of lung cancer (12-16). MAGE family member A (MAGEA) has also been used as immunogenic target gene, and for adjuvant immunotherapy using vaccination with MAGEA3 fusion protein in resected MAGEA3 positive lung cancer, which is currently ongoing Phase III clinical trials $(17,18)$.

Compelling evidence has been reported that MAGEA2 blocks the association between the potent tumor suppressor p53 and its cognate sites on chromatin, silencing the downstream p53-dependent transactivation during tumor development (19). MAGEA2 also binds histone deacetylase 3 , suppresses $\mathrm{p} 53$-dependent apoptosis in response to chemotherapeutic drugs, decreases cellular senescence and increases cell proliferation $(20,21)$. However, genetic p53 mutations are found in approximately 50\% of NSCLC and 70\% of small cell carcinoma (SCC) (22). Although it is recognized that the functional loss of p53 has an established role in the lung carcinogenesis, other multiple mechanisms of activation and inactivation are thought to also contribute to the progression of lung cancer (23-25). Currently, little is known about the relationship between MAGEA genes and p53 aberrant expression in lung cancer.

In the present study, we examined the expression of MAGEA2 in human lung cancer, and the role of MAGEA2 in cancer cell growth and/or survival using lung cancer cell lines with p53 mutation. We then examined its clinicopathologic significance and evaluated MAGEA2 expression as a prognostic biomarker according to histology and p53 expression. Our results demonstrate the functional role of MAGEA2 in p53 aberrant lung tumors and the therapeutic and prognostic potential of targeting MAGEA2 for lung cancer.

\section{Materials and methods}

Lung cancer clinical EBUS samples and tissue samples. Thirty-one samples obtained via EBUS-TBNA from metastatic LNs in patients with advanced lung cancers, including 13 lung adenocarcinomas (ADCs), eight lung squamous cell carcinomas (SqCCs), five lung large cell carcinomas (LCCs), and five small cell lung cancers (SCCs) were used (Toronto General Hospital, Toronto, ON, Canada, study number: 11-0109-CE). Thirty-six of the primary lung cancer samples, including 23 lung ADCs and 13 lung SqCCs, paired with normal lung tissue were also used in this study, and a total
RNA of 21 normal human tissues (Human Total RNA Master Panel II) were purchased from Clontech Laboratories, Inc. (Mountain View, CA, USA) to detect MAGEA2 expression in normal tissue distribution. A total of 353 lung cancer and adjacent normal lung tissue samples to be used for immunohistochemical (IHC) staining on tissue microarrays (TMA) and additional statistical analysis were obtained from patients who underwent surgery at Hokkaido University and its affiliated hospitals with informed consent (26-28). These were consecutive patients with lung cancer who underwent surgical lobectomy or pneumonectomy. Detailed clinical and pathological information was collected retrospectively for all patients.

Histopathological examination of resected tumors revealed that ADC was the dominant histological group (241 cases), followed by 89 cases of SqCC, 19 cases of LCC, and 4 cases of SCC. Postoperative staging evaluation identified stage IA disease in 120 cases, stage IB disease in 108 cases, stage IIA disease in 38 cases, stage IIB disease in 27 cases, stage IIIA disease in 57 cases, and stage IIIB disease in 3 cases. Follow-up lasted through October 30, 2009, with a median follow-up period of 60.5 months for living patients (range, 48.1-165.8 months). The primary end point was overall survival as measured from the date of surgery to the time of death of the patients. All specimens were fixed in formalin and embedded in paraffin wax. Representative blocks were selected (based primarily on greatest dimensions of each tumor), and serial $4-\mu \mathrm{m}$-thick sections were examined by immunohistochemistry. Histological diagnoses of tumors were based on the 2015 World Health Organization Classification (29). All tumors were staged according to the pathological tumor/node/metastasis (pTNM) classification (7th edition) of the American Joint Committee on Cancer (30). All available hematoxylin and eosin (H\&E) stained tumor slides were histologically reviewed by a pathologist.

Lung cancer cell lines. The human lung cancer cell lines used in this study were as follows: lung ADC NCI-H1437; lung LCC H661; and lung SCC SBC-5. All cancer cells were grown in monolayers in appropriate medium supplemented with $10 \%$ FCS and were maintained at $37^{\circ} \mathrm{C}$ in atmospheres of humidified air with $5 \% \mathrm{CO}_{2}$.

Specimen handling and EBUS-TBNA sample preparation. EBUS-TBNA was performed as previously described (31). Briefly, a dedicated 22-gauge needle equipped with an internal stylet was used (NA-201SX-4022; Olympus, Japan). Multiple passes were performed from the target LNs. After confirmation of adequate sampling for cytological evaluation, an additional pass was performed for the preservation of RNA. The aspirate was mixed with Allprotect Tissue Reagent ${ }^{\circledR}$ (Qiagen, Valencia, CA) following the manufacturer's instructions and stored at $-80^{\circ} \mathrm{C}$. The samples were equilibrated to room temperature, and the stabilizing solution was completely removed. QIAzol Lysis Reagent (Qiagen) and one 5-mm stainless steel bead (Qiagen) were added before homogenizing with a TissueLyser Adapter Set (Qiagen) for $2 \mathrm{~min}$ at $20 \mathrm{~Hz}$. Total RNA was then purified using a miRNeasy mini kit (Qiagen). The amount and purity were measured using a spectrophotometer (NanoDrop; Thermo Scientific, Wilmington, DE, USA). 


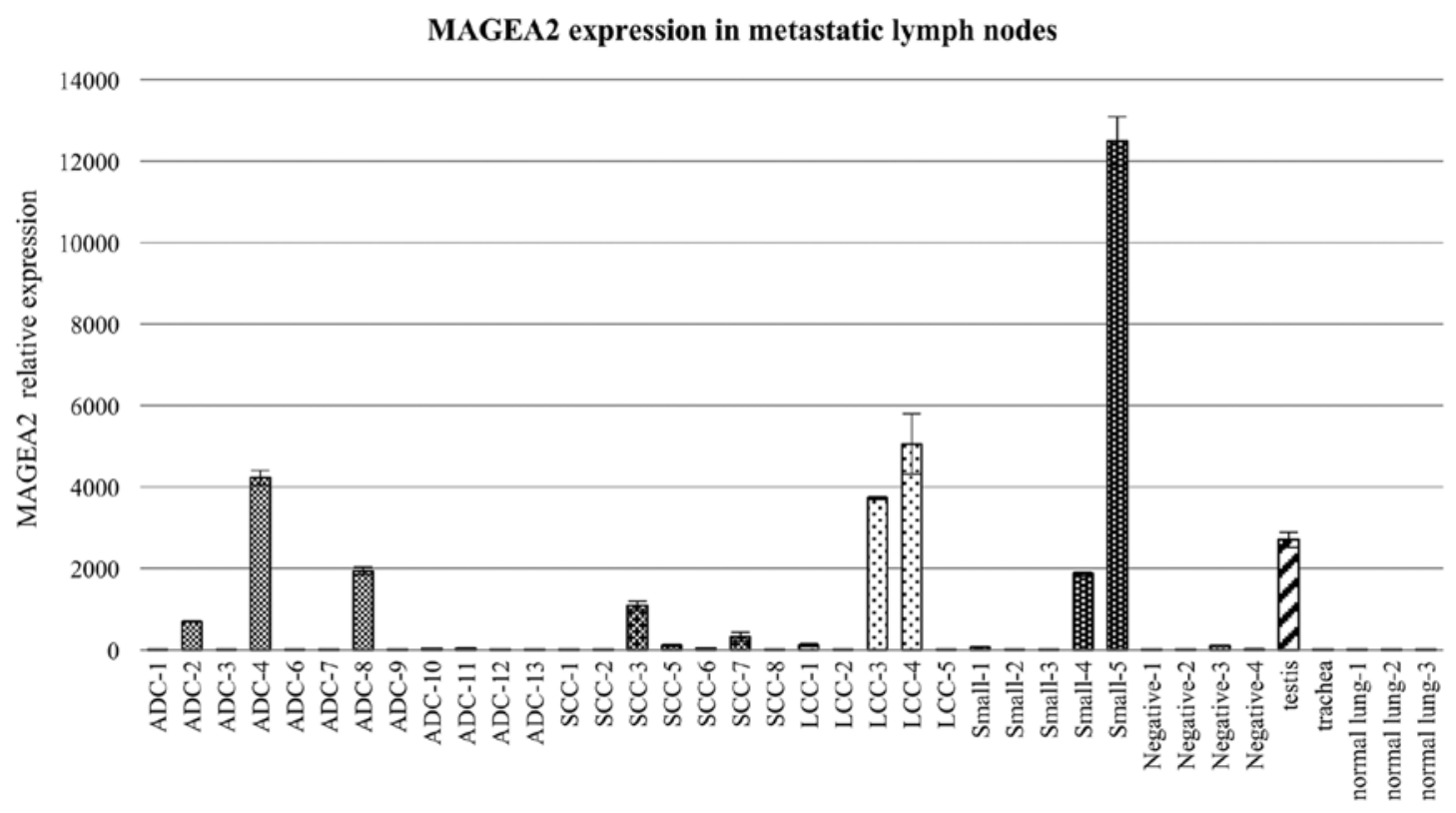

Figure 1. Expression of MAGEA2 in metastatic lymph nodes samples. Quantitative reverse transcription-polymerase chain reaction (qRT-PCR) analysis in metastatic lymph node samples from advanced lung cancer. The relative expression levels were normalized to the ACTB level in each sample and calculated as the threshold cycle value in each sample divided by the average threshold cycle values in normal lung. Error bars represent the standard error of the mean (SEM) of duplicate. ADC, adenocarcinoma; LCC, large cell carcinoma; SCC, small cell carcinoma; Negative; no malignancy lymph node samples.

Quantitative RT-PCR analysis. The cDNA was synthesized from $2 \mu \mathrm{g}$ total RNA using QuantiTect ${ }^{\circledR}$ Reverse Transcription kit (Qiagen). The primers were designed as follows: for MAGEA2, A2B, forward primer, 5'-gggacaggctgacaagtagg-3', and reverse primer 5'-ttgcagtgctgactcctctg-3'; for p21, forward primer, 5'-gcagaccagcatgacagattt-3' and reverse primer 5'-ggatt agggettcctcttgga-3'; for MDM2, forward primer, 5'-ggatttcgg acggctctcgc-3' and reverse primer 5'-cgcgcagcgttcacactactg-3'; for actin, $\beta$ (ACTB), forward primer, 5'-gaaatcgtgcgtgacattaa-3', and reverse primer, 5'-aaggaaggctggaagagtg-3'. qRT-PCR analysis was performed using LightCycler $480{ }^{\circledR}$ SYBR Green I Master Ready-to-use hot start reaction mix and LightCycler 480 system (Roche, South San Francisco, CA, USA). The thermal cycler conditions were as follows: $5 \mathrm{~min}$ at $95^{\circ} \mathrm{C}$ for denaturation, 45 cycles at $95^{\circ} \mathrm{C}$ for $10 \mathrm{sec}, 56^{\circ} \mathrm{C}$ for $10 \mathrm{sec}$, and $72^{\circ} \mathrm{C}$ for $10 \mathrm{sec}$ for PCR amplification, and $1 \mathrm{~min}$ at $65^{\circ} \mathrm{C}$ for melting. The threshold cycle value was defined as the value obtained in the PCR cycle when the fluorescence signal increased above the background threshold. PCR reactions were carried out in duplicates.

RNA interference and cell viability assay. All siRNA oligonucleotide sequences for this study were purchased from Qiagen. Negative Control siRNA and AllStar ${ }^{\circledR}$ Negative Control siRNA (Qiagen) were used as the negative control (NC-siRNAs-\#1, -\#2). siRNAs with a final concentration of 5-10 nM were incubated with HiPerFect ${ }^{\circledR}$ Transfection Reagent (Qiagen) according to the manufacturer's instructions. The CellTiter $96^{\circledR}$ AQueous One Solution Cell Proliferation Assay (Promega, Madison, WI, USA) was used for the evaluation of the number of viable cells according to the manufacturer's instructions, and measured using a microplate spectrophotometer ( $\mu$ Quant; Bio-Tek Inc., Winooski, VT, USA). Each experiment was performed in triplicates.
Tissue microarray construction and immunohistochemistry. Tissue areas for sampling were selected based on visual alignment with the corresponding H\&E stained sections on slides. A core (diameter, $2 \mathrm{~mm}$; height, 3-5 mm) taken from each donor-tumor block was placed into a recipient block using a tissue microprocessor (Azumaya Medical Instruments, Tokyo, Japan). MAGEA2 [anti-MAGEA2 antibody (ab64894), Abcam Japan, Tokyo, Japan] and p53 immunostaining [DO-7 anti-human p53 mouse monoclonal antibody (Dako Japan, Tokyo, Japan)] were performed using an automated IHC platform (Autostainer Plus, Dako, Carpinteria, CA, USA). Antigen retrieval was performed in $\mathrm{pH} 9.0$ for $20 \mathrm{~min}$. EnVision $^{\mathrm{TM}}+$ Dual Link (K4063, Dako) was used for detection, with post-primary incubation for $60 \mathrm{~min}$ at room temperature. A polymer-based detection system $\left(\right.$ EnVision $^{\mathrm{TM}}+$ Dual Link \#K4063, Dako) was used with 3', 3-diaminobenzidine (DAB) as the chromogen. The positive control included a sample of testis, and normal lung samples were used as negative controls. Slides were dehydrated and placed on coverslips.

Evaluation of immunohistochemical staining. Digital images of IHC-stained TMA slides were obtained at x20 magnification using a whole slide scanner (ScanScope CS, Aperio ePathology; Leica Microsystems Inc., ON, Canada). Images were saved in SVS format (Aperio) and annotation of tumor regions on whole slides was performed blinded to clinical follow-up data using Aperio annotation software (ImageScope Viewing Software, Positive Pixel Count version 9.1, Aperio) (32). MAGEA2 was quantified by IHC scoring, which summated the percentage of area stained at each intensity level multiplied by the weighted intensity $(0,1,2$, or 3$)$ reported in other studies (33-36). Initially, the weighted intensity of staining was graded as follows; grade 0 (negative), $1+$ [weak positive: intensity Threshold Weak (upper limit) $=240$, (lower limit) $=220$ ], 


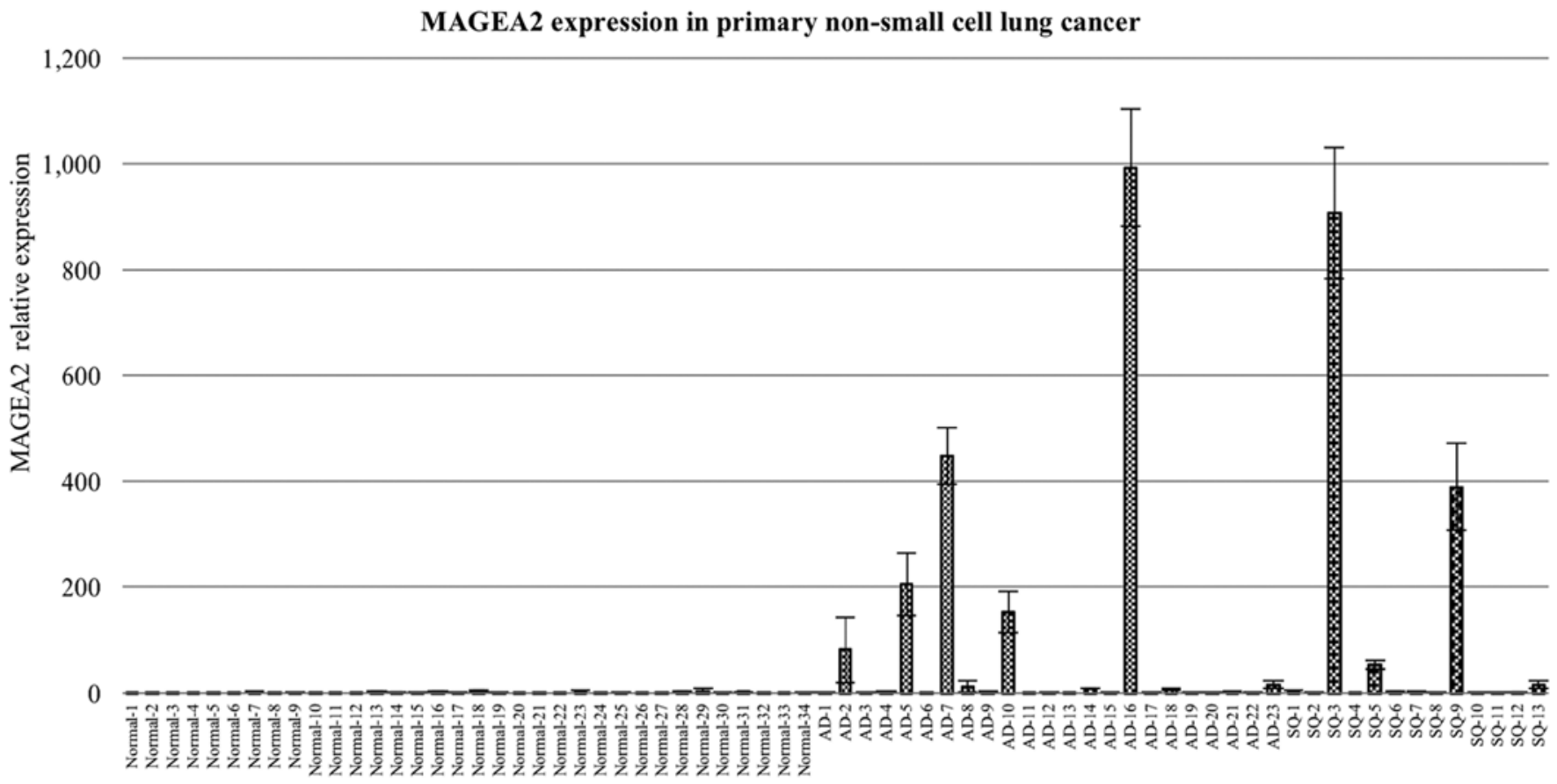

Figure 2. Expression of MAGEA2 in primary non-small cell lung cancer (NSCLC). Mean messenger RNA expression as measured by means of qRT-PCR in primary tissue from paired 34 lung cancer and normal tissue were used for this analysis. Normal, normal lung; AD, adenocarcinoma; SQ, squamous cell carcinoma.

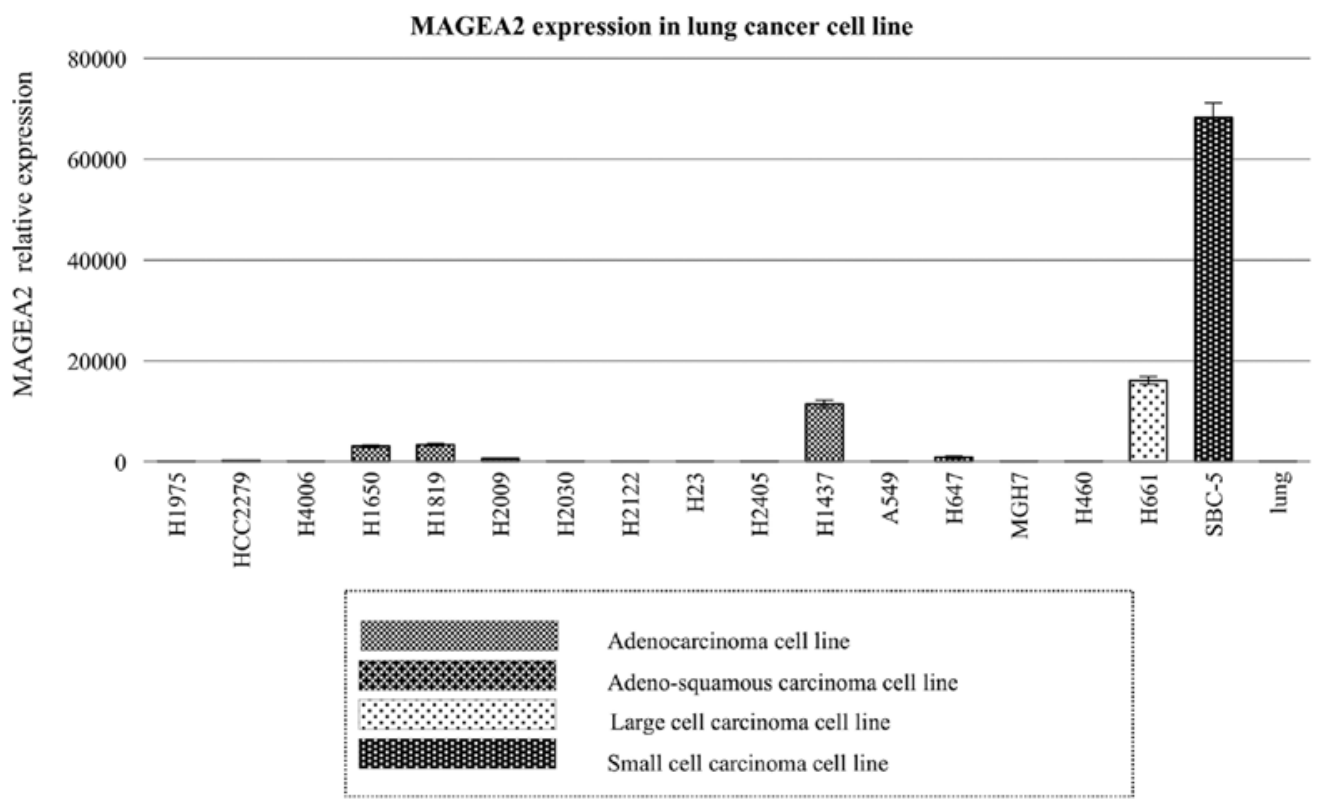

Figure 3. MAGEA2 expression in lung cancer cell lines. Mean messenger RNA expression as measured by means of qRT-PCR in primary tissue from 17 lung cancer cell lines and normal lung were used for this analysis.

$2+[$ moderate positive: Medium (upper) $=220,($ lower $)=180)]$, and $3+$ (strong positive: Strong (upper) $=180,($ lower $)=0)$ according to Aperio annotation software). According to the total amount of IHC scores, MAGEA2 was dichotomized into high versus low using optimal cut-points, which were found using a maximally selected log-rank statistics: low-level MAGEA2 expression (Low-MAGEA2, with an IHC score <0.65) and high-level MAGEA2 expression (High-MAGEA2, with an IHC score $\geq 0.65$ ). For p53 evaluation, each core was scored semi-quantitatively for the degree of positive nuclear expression in tumor cell under a high-power field (magnification, x200). Percentage of positive nuclear expression was calculated. p53 IHC was defined as 'aberrant expression' if tumor cells showed either nuclear expression in $>50 \%$ or complete absence of staining and as 'wild-type expression' if tumor cells showed no aberrant expression (1-50\% staining) (36-39).

Statistical analysis. We attempted to correlate clinicopathological variables such as age, gender, pathological TNM stage, pleural invasion, histological classification, and smoking 
Table I. Patient characteristics according to MAGEA2 and p53 expression levels for all patients.

\begin{tabular}{|c|c|c|c|c|c|c|c|c|c|c|}
\hline \multirow[b]{3}{*}{ Patient characteristics } & \multicolumn{5}{|c|}{ MAGEA2 expression } & \multicolumn{5}{|c|}{ p53 expression } \\
\hline & \multicolumn{2}{|c|}{ Low } & \multicolumn{2}{|c|}{ High } & \multirow[b]{2}{*}{ P-value } & \multicolumn{2}{|c|}{ Wild-type } & \multicolumn{2}{|c|}{ Aberrant } & \multirow[b]{2}{*}{ P-value } \\
\hline & $\mathrm{N}$ & $\%$ & $\mathrm{~N}$ & $\%$ & & $\mathrm{~N}$ & $\%$ & $\mathrm{~N}$ & $\%$ & \\
\hline All patients & 132 & 37 & 221 & 63 & & 176 & 50 & 177 & 50 & \\
\hline Age (years) & & & & & 0.908 & & & & & 1.000 \\
\hline$<60$ & 46 & 38 & 76 & 62 & & 61 & 50 & 61 & 50 & \\
\hline$\geq 60$ & 86 & 37 & 145 & 63 & & 115 & 50 & 116 & 50 & \\
\hline Gender & & & & & 0.818 & & & & & 0.436 \\
\hline Female & 47 & 38 & 76 & 62 & & 65 & 53 & 58 & 47 & \\
\hline Male & 85 & 37 & 145 & 63 & & 111 & 48 & 119 & 52 & \\
\hline Smoking history & & & & & 0.642 & & & & & 0.056 \\
\hline Never-smoker & 42 & 35 & 77 & 65 & & 68 & 57 & 51 & 43 & \\
\hline Smoker & 90 & 38 & 144 & 62 & & 108 & 46 & 126 & 54 & \\
\hline Histological classification & & & & & 0.556 & & & & & 0.341 \\
\hline $\mathrm{ADC}$ & 95 & 39 & 146 & 61 & & 127 & 53 & 114 & 47 & \\
\hline $\mathrm{SqCC}$ & 30 & 34 & 59 & 66 & & 41 & 46 & 48 & 54 & \\
\hline LCC & 5 & 26 & 14 & 74 & & 7 & 37 & 12 & 63 & \\
\hline SCC & 2 & 50 & 2 & 50 & & 1 & 25 & 3 & 75 & \\
\hline pT factor & & & & & 0.309 & & & & & 0.029 \\
\hline pT1 & 46 & 34 & 90 & 66 & & 78 & 57 & 58 & 43 & \\
\hline pT2-4 & 86 & 40 & 131 & 60 & & 98 & 45 & 119 & 55 & \\
\hline $\mathrm{pN}$ factor & & & & & 0.374 & & & & & 0.176 \\
\hline pNO & 103 & 39 & 162 & 61 & & 138 & 52 & 127 & 48 & \\
\hline pN1-2 & 29 & 33 & 59 & 67 & & 38 & 43 & 50 & 57 & \\
\hline Pathologic stage & & & & & 0.054 & & & & & 0.041 \\
\hline Stage I & 85 & 37 & 143 & 63 & & 120 & 53 & 108 & 47 & \\
\hline Stage II & 31 & 48 & 34 & 52 & & 35 & 54 & 30 & 46 & \\
\hline Stage III & 16 & 27 & 44 & 73 & & 21 & 35 & 39 & 65 & \\
\hline Pleural invasion & & & & & 0.109 & & & & & 0.100 \\
\hline Absent & 75 & 34 & 144 & 66 & & 117 & 53 & 102 & 47 & \\
\hline Present & 57 & 43 & 77 & 57 & & 59 & 44 & 75 & 56 & \\
\hline p53 expression & & & & & 0.001 & & & & & \\
\hline Wild-type & 96 & 55 & 80 & 45 & & - & & - & & \\
\hline Aberrant & 36 & 20 & 141 & 80 & & - & & - & & \\
\hline
\end{tabular}

ADC, adenocarcinoma; SqCC, squamous cell carcinoma; LCC, large cell carcinoma; SCC, Small cell carcinoma; CI, confidence interval. Significant $\mathrm{P}$-values $(<0.05)$ are shown in bold. P-value was analyzed using the Pearson's $\chi^{2}$ test.

history with expression levels of MAGEA2 protein and aberrant p53 as determined by TMA analysis. MAGEA2 and aberrant p53 immunoreactivities were assessed for association with clinicopathologic variables using the $\chi^{2}$ test for variables. Overall survival (OS) was estimated using the Kaplan-Meier method starting at the time of surgery. Patients who survived during study follow-up were censored at the last time they were known to be alive. Differences in OS between patient subgroups were compared using the log-rank test. Multivariate analysis was performed using the Cox proportional hazards regression model to estimate the effect of markers of interest on OS, with adjustments for the clinicopathologic factors that were found to be significantly associated with OS in univariate analyses. All significance tests were two-sided and used a 5\% level of significance. In vitro experiments, tumor treated with MAGEA2 vs. no transfection were analyzed by paired Student's t-test. Statistical analyses were conducted using the 'survival' and 'maxstat' packages in $\mathrm{R}$ (version 3.0.1; R Development Core Team).

\section{Results}

Transcriptional expression of MAGEA2 in lung tumors and normal tissues. Expression of MAGEA2 was significantly 

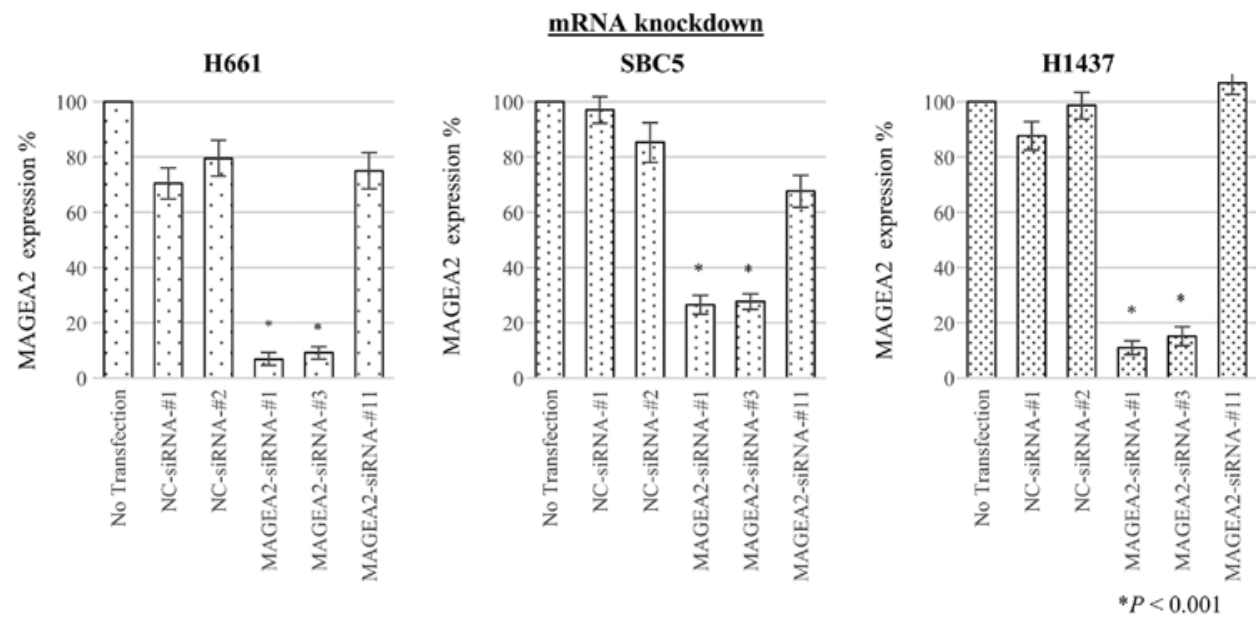

Figure 4. Effects of MAGEA2 short interfering RNA (siRNA) on lung cancer cell proliferation in vitro. Effects of siRNA on mRNA expression levels. qRT-PCR analysis of gene expression in each lung cancer cell lines with p53 mutation (H661, SBC5 and H1437) treated with negative control siRNAs (NC-siRNA-\#1,\#2) and different gene-specific siRNAs. mRNA levels of each cancer cell line transfected with independent siRNAs targeting MAGEA2 gene was significantly decreased in comparison with cells transfected with control siRNAs $48 \mathrm{~h}$ after transfection. Results shown are mean \pm SEM (bars) ("P $<0.001$, paired Student's t-test).
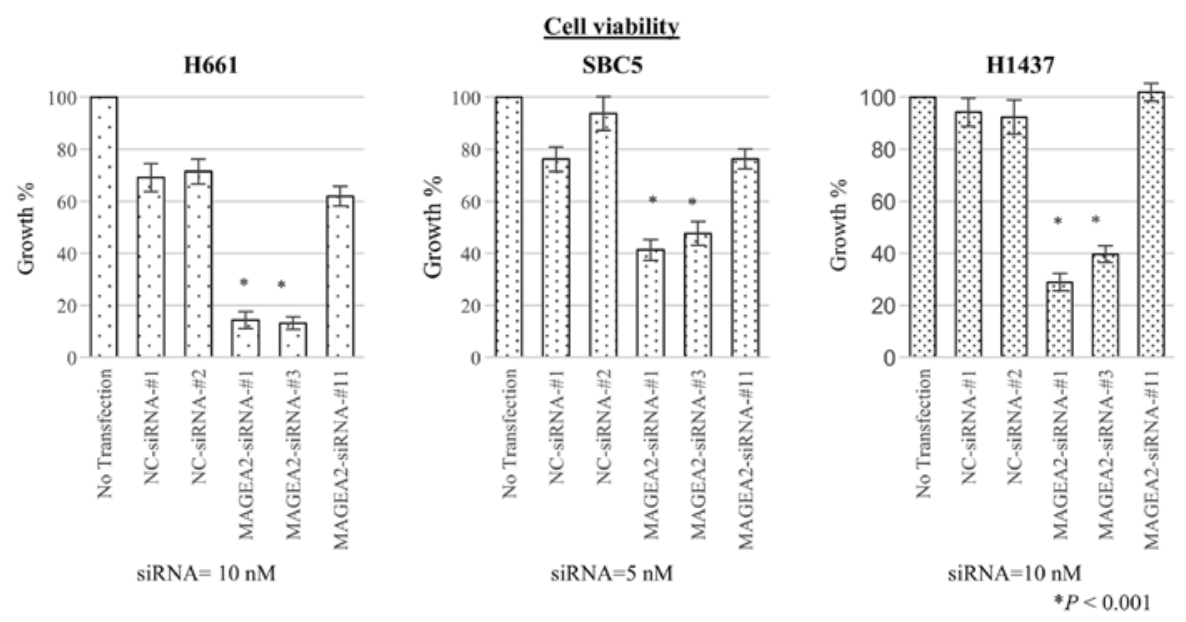

Figure 5. Effect of each siRNA on lung cancer cell proliferation in vitro: Cells were treated with siRNAs for $96 \mathrm{~h}$, and cell viability was determined using cell proliferation assay. After siRNA treatments, the proliferation in MAGEA2 gene cells was evaluated compared with control groups at 4 days after transfection, resulting in the identification of potential MAGEA2 therapeutic candidate genes. Gene knockdown in lung cancer cell lines identified cell viability inhibition following knockdown of MAGEA2 gene. Results shown are mean \pm SEM (bars) of three experiments ("P<0.001, paired Student's t-test).

higher in metastatic lymph node samples obtained from patients with advanced lung cancer with EBUS-TBNA compared to those taken from healthy individuals and non-malignant (negative) LN tissues (Fig. 1). MAGEA2 expression was also higher in primary tissue from 34 lung cancer samples taken, from patients who underwent surgery, of which 23 had lung ADCs and 13 had lung SqCCs, compared to paired normal lung tissue (Fig. 2). qRT-PCR analysis using cDNA panel containing normal human tissues also identified MAGEA2 as being expressed only in the testis with almost no expression in the other vital organs (data not shown). We also confirmed high expression levels of MAGEA2 using 17 lung cancer cell lines (Fig. 3). This step also allowed identification of relevant cell lines for RNAi experiments.

Growth inhibition of lung cancer cells by specific siRNA against candidate genes. To assess whether MAGEA2 is essential for growth of lung-cancer cells, we transfected 3 different types of target-specific siRNAs against MAGEA2 (MAGEA2siRNAs-\#1, \#3, \#11) as well as two different negative control siRNAs (NC-siRNAs-\#1, -\#2) into H661, SBC5, and H1437 lung cancer cell lines. qRT-PCR showed that the mRNA levels of each cancer cell transfected with two of the three siRNAs targeting MAGEA2 gene (MAGEA2-siRNAs-\#1 and-\#3) were significantly decreased in comparison with cells transfected with control siRNAs $48 \mathrm{~h}$ after transfection (Fig. 4). Next, to evaluate the effect of MAGEA2 gene knockdown on cell proliferation, we conducted a cell viability assay. Proliferation of lung cancer cells transfected with these two siRNAs was significantly suppressed compared to control groups at 4 days after transfection, suggesting that upregulation of MAGEA2 is associated with survival of lung cancer cells (Fig. 5).

MAGEA2 regulates p53 targets (BAX, CDKN1A, and $M D M 2)$ in lung cancer cell lines. To determine the effects of regulating MAGEA2 on the expression level of 3 main p53 


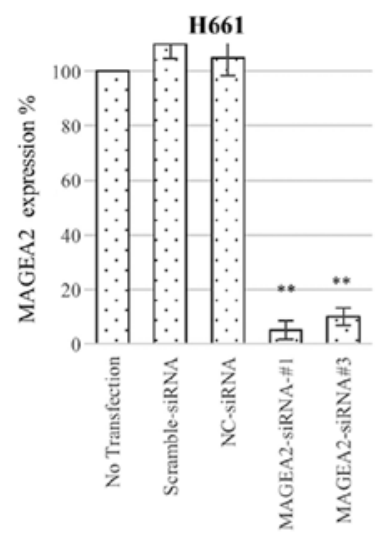

MAGEA2 relative expression
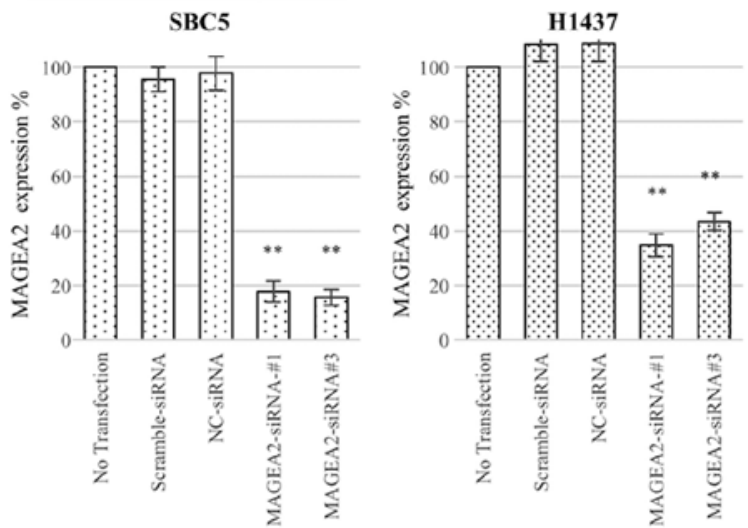

$\underline{B A X}$ relative expression

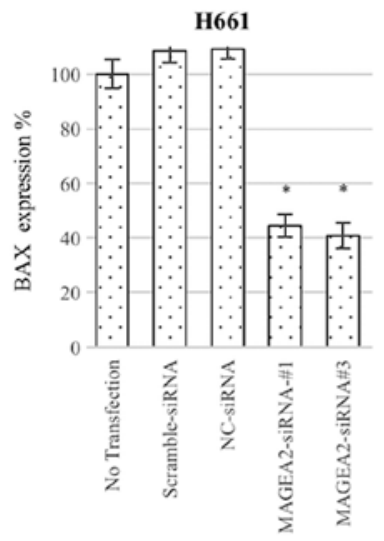

SBC5
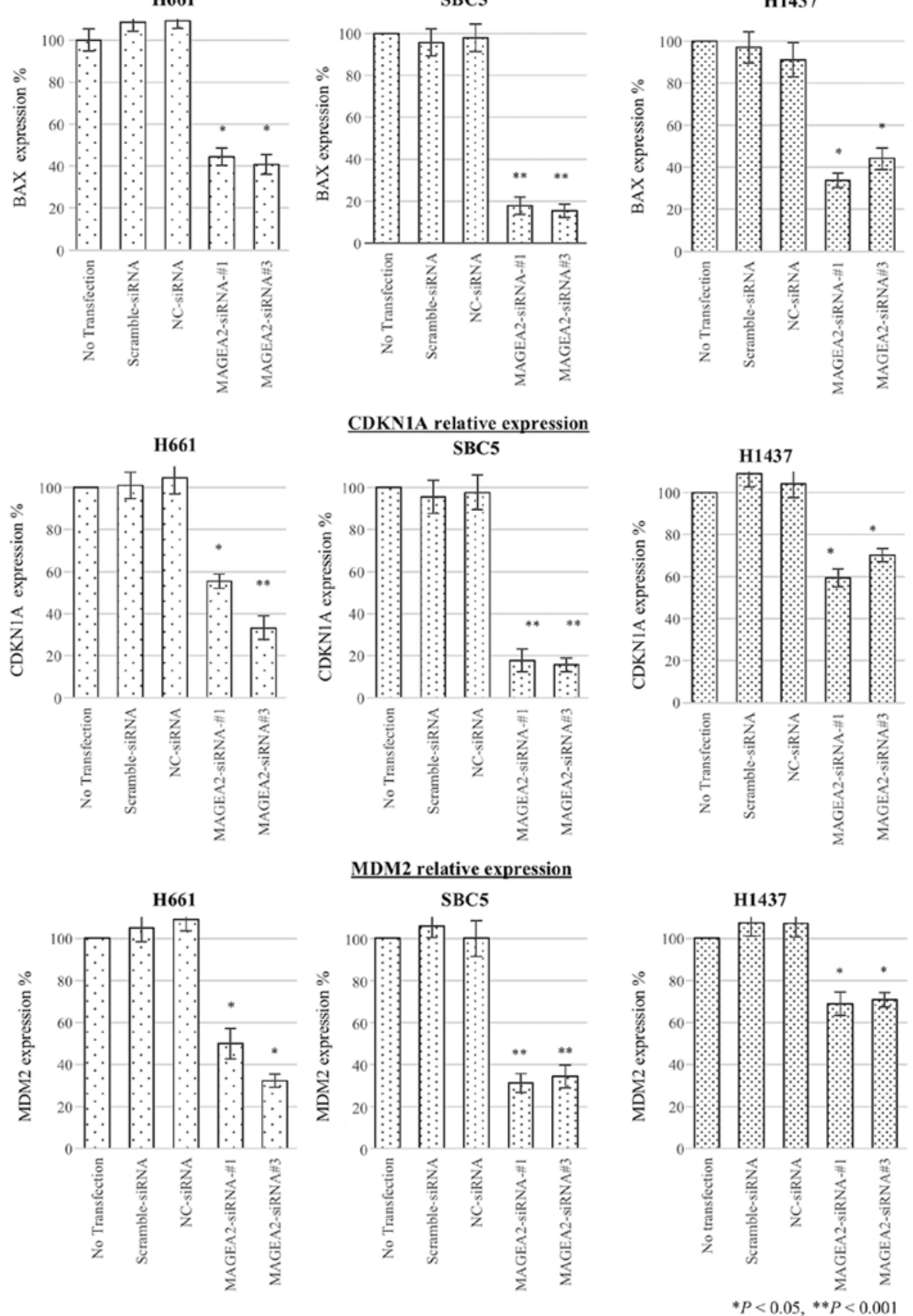

Figure 6. Expression of p53 downstream targets after suppression of MAGEA2 in lung cancer cells. MAGEA2, BAX, CDKN1A, and MDM2 expression adjusted to \% of no transfection. Each gene were significantly downregulated in each lung cancer cell line (H661, SBC5 and H1437). Results shown are mean \pm SEM (bars) $\left({ }^{*} \mathrm{P}<0.05,{ }^{* *} \mathrm{P}<0.001\right.$, paired Student's t-test). 


\section{MAGEA2 expression}

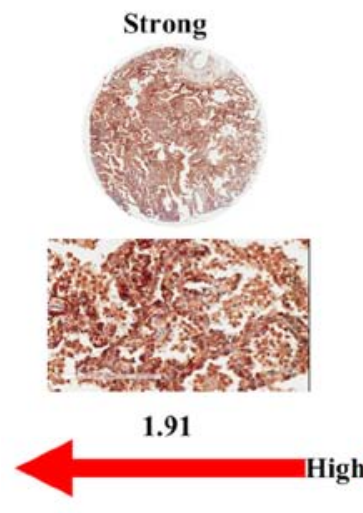

High

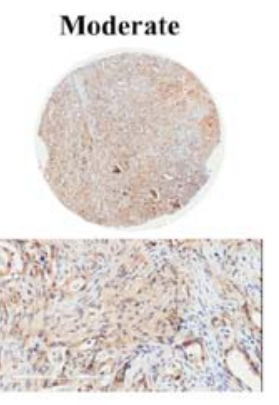

1.00

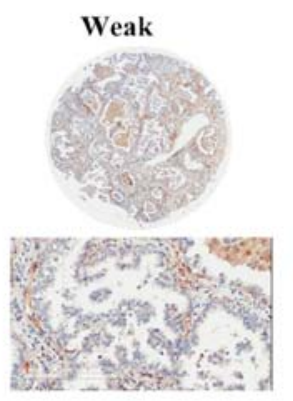

0.50

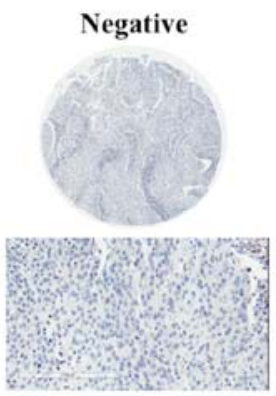

0.03
No expression

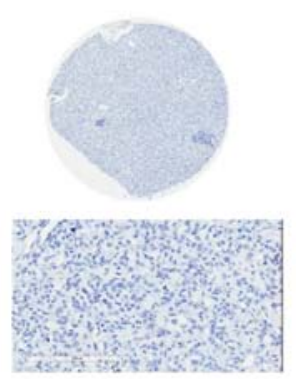

$0 \%$
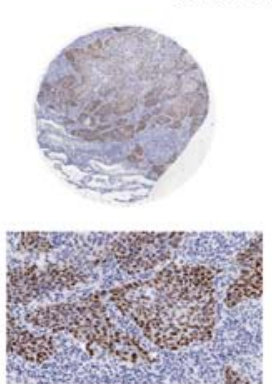

$80 \%$
Over $\mathbf{5 0} \%$

\section{p53 expression}
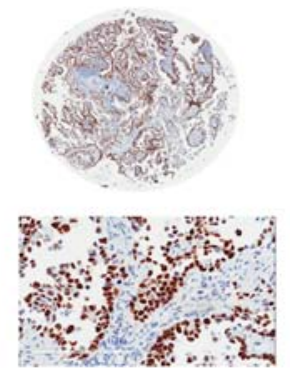

$60 \%$
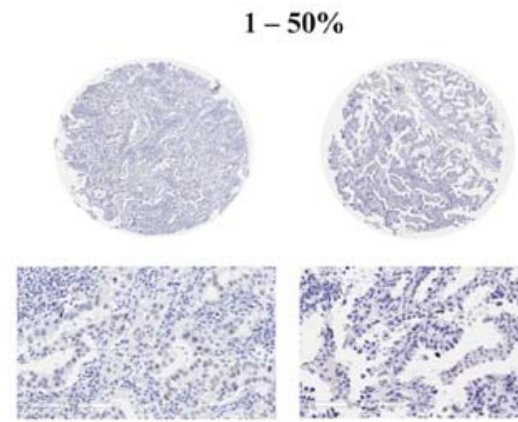

$30 \%$

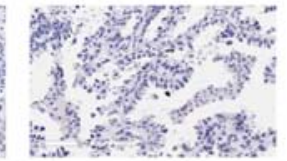

$10 \%$

Figure 7. Representative examples of MAGEA2 protein expression in lung adenocarcinoma (ADC). Intensity and proportion scores were multiplied together to obtain the immunohistochemical (IHC) score. MAGEA2 expression was defined as 'High expression' if IHC score is greater than 0.65 and as 'Low expression' if IHC score is $<0.65$. Expression of aberrant p53 in lung cancer nucleus. Percentage of positive nuclear expression was calculated. p53 IHC was defined as 'aberrant expression' if tumor cells showed either nuclear expression in $>50 \%$ or complete absence of staining and as 'wild-type expression' if tumor cells showed no aberrant expression (1-50\% staining).

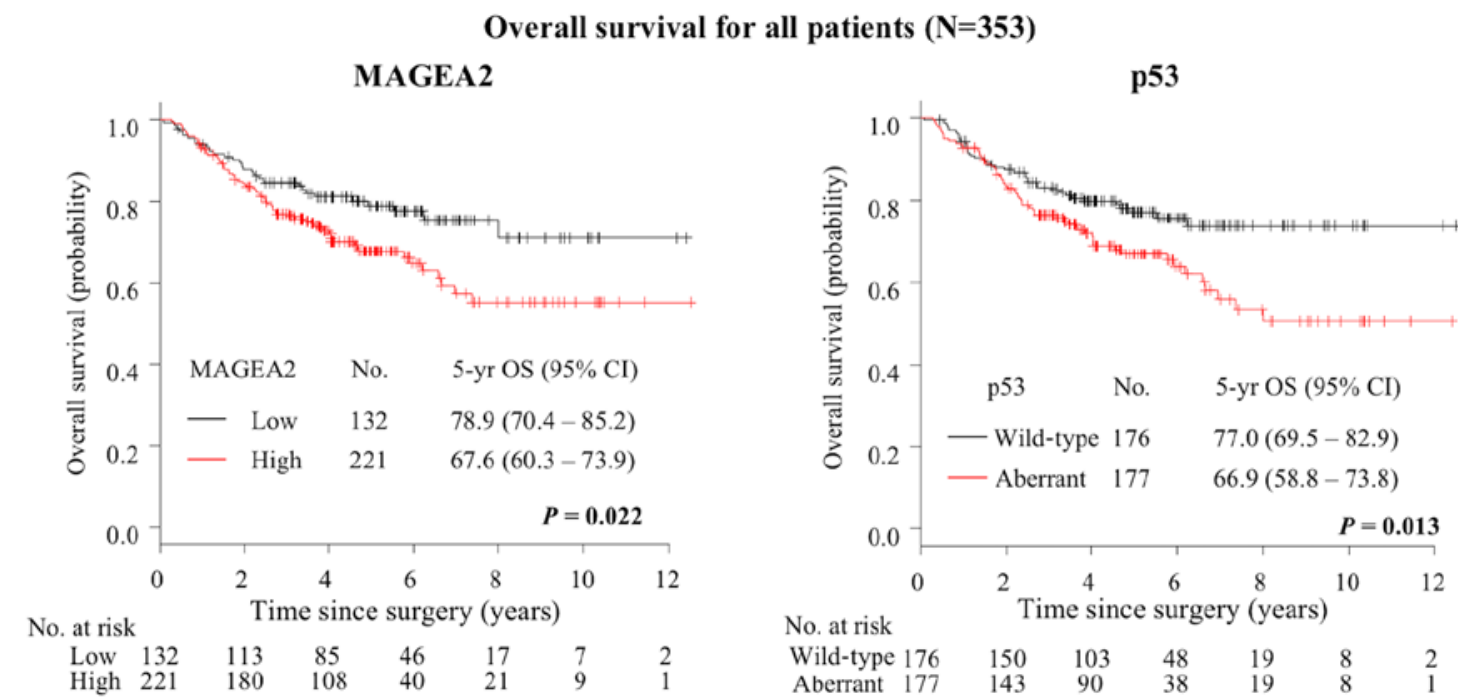

Figure 8. Expression of MAGEA2 and p53 protein and prognostic impact on lung cancers. Kaplan-Meier analysis of overall survival in all patients according to MAGEA2 and aberrant p53 expression level and combination of MAGEA2 and aberrant p53. The 5-year overall survival (OS) rate was $78.9 \%$ for patients with low expression of MAGEA2 $(\mathrm{n}=132)$, whereas $67.6 \%$ for patients with high expression of MAGEA2 $(\mathrm{n}=221)(\mathrm{P}=0.022)$. The 5 -year OS rate was $77.0 \%$ for patients with wild-type $\mathrm{p} 53$ expression $(\mathrm{n}=176)$, and $66.9 \%$ for patients with aberrant $\mathrm{p} 53$ expression $(\mathrm{n}=177)(\mathrm{P}=0.013)$.

downstream target genes, BAX, CDKN1A, and MDM2, we performed qRT-PCR after transient transfection of siRNA against MAGEA2 in lung cancer cell lines with p53 mutation (H661, SBC5, H1437). Subsequently, inhibition of MAGEA2 
Table II. Patient characteristics according to MAGEA2 and p53 expression levels for adenocarcinoma.

\begin{tabular}{|c|c|c|c|c|c|c|c|c|c|c|}
\hline \multirow[b]{3}{*}{ Patient characteristics } & \multicolumn{5}{|c|}{ MAGEA2 expression } & \multicolumn{5}{|c|}{ p53 expression } \\
\hline & \multicolumn{2}{|c|}{ Low } & \multicolumn{2}{|c|}{ High } & \multirow[b]{2}{*}{ P-value } & \multicolumn{2}{|c|}{ Wild-type } & \multicolumn{2}{|c|}{ Aberrant } & \multirow[b]{2}{*}{ P-value } \\
\hline & $\mathrm{N}$ & $\%$ & $\mathrm{~N}$ & $\%$ & & $\mathrm{~N}$ & $\%$ & $\mathrm{~N}$ & $\%$ & \\
\hline All patients & 95 & 39 & 146 & 61 & & 127 & 53 & 114 & 47 & \\
\hline Age (years) & & & & & 0.687 & & & & & 0.513 \\
\hline$<60$ & 36 & 38 & 60 & 63 & & 48 & 50 & 48 & 50 & \\
\hline$\geq 60$ & 59 & 41 & 86 & 59 & & 79 & 54 & 66 & 46 & \\
\hline Gender & & & & & 1.000 & & & & & 0.158 \\
\hline Female & 44 & 40 & 67 & 60 & & 64 & 58 & 47 & 42 & \\
\hline Male & 51 & 39 & 79 & 61 & & 63 & 49 & 67 & 52 & \\
\hline Smoking history & & & & & 0.425 & & & & & 0.056 \\
\hline Never-smoker & 38 & 36 & 67 & 64 & & 63 & 60 & 42 & 40 & \\
\hline Smoker & 57 & 42 & 79 & 58 & & 64 & 47 & 72 & 53 & \\
\hline $\mathrm{pT}$ factor & & & & & 1.000 & & & & & 0.027 \\
\hline pT1 & 41 & 40 & 62 & 60 & & 63 & 61 & 40 & 39 & \\
\hline pT2-4 & 54 & 39 & 84 & 61 & & 64 & 46 & 74 & 54 & \\
\hline $\mathrm{pN}$ factor & & & & & 0.874 & & & & & 0.161 \\
\hline pN0 & 75 & 40 & 113 & 60 & & 104 & 55 & 84 & 45 & \\
\hline $\mathrm{pN} 1-2$ & 20 & 38 & 33 & 62 & & 23 & 43 & 30 & 57 & \\
\hline Pathologic stage & & & & & 0.315 & & & & & 0.065 \\
\hline Stage I & 68 & 40 & 102 & 60 & & 94 & 55 & 76 & 45 & \\
\hline Stage II & 16 & 47 & 18 & 53 & & 20 & 59 & 14 & 41 & \\
\hline Stage III & 11 & 30 & 26 & 70 & & 13 & 35 & 24 & 65 & \\
\hline Pleural invasion & & & & & 0.412 & & & & & 0.284 \\
\hline Absent & 57 & 37 & 96 & 63 & & 85 & 56 & 68 & 44 & \\
\hline Present & 38 & 43 & 50 & 57 & & 42 & 48 & 46 & 52 & \\
\hline p53 expression & & & & & $<0.001$ & & & & & \\
\hline Wild-type & 78 & 61 & 49 & 39 & & - & & - & & \\
\hline Aberrant & 17 & 15 & 97 & 85 & & - & & - & & \\
\hline
\end{tabular}

Significant P-values $(<0.05)$ are shown in bold. P-value was analyzed using the Pearson's $\chi^{2}$ test.

induced a decrease in messenger RNA expression of these p53 downstream target genes, suggesting MAGEA2 was able to stimulate p53 transactivation function (Fig. 6).

Pattern of MAGEA2 and p53 expression and its clinicopathological correlation. To determine the clinical relevance of the MAGEA2, we assessed MAGEA2 protein and aberrant p53 expression using TMA analysis, MAGEA2 and p53 expression were categorized as previously described (34-36). The representative staining and its IHC score of lung ADC cases are shown in Fig. 7. Positive staining of MAGEA2 in tumor cells generally showed a cytoplasmic pattern in cancer tissue. Of the 353 lung cancer cases examined, High-MAGEA2 was observed in 221 cases $(63 \%)$. Of those, $146 \mathrm{ADCs}(61 \%), 59 \mathrm{SqCCs}(66 \%)$, 14 LCCs $(74 \%)$, and 2 SCCs (50\%) showed High-MAGEA2. We then proceeded to correlate MAGEA2 expression and aberrant p53 combinations with various clinicopathological parameters in all patients (Table I). High-MAGEA2 levels were strongly correlated with aberrant p53 expression $(\mathrm{P}=0.001)$. Aberrant expression of p53 was also correlated with $\mathrm{pT}$ factor $(\mathrm{P}=0.029)$ and pathological stage $(\mathrm{P}=0.041)$. We then examined any correlations between MAGEA2 and p53 expression using subset analyses according to histology. In ADC patients (Table II), High-MAGEA2 was strongly associated with aberrant $\mathrm{p} 53$ expression $(\mathrm{P}<0.001)$ and this change in $\mathrm{p} 53$ levels was correlated with $\mathrm{pT}$ factor in patients with ADC $(\mathrm{P}=0.027)$. In SqCC patients (Table III), High-MAGEA2 was strongly associated with $\mathrm{pT}$ factor $(\mathrm{P}=0.046)$. Association between MAGEA2 expression and p53 expression was not observed in SqCC patients $(\mathrm{P}=0.656)$.

Prognostic significance of MAGEA2 and p53 expression. At the end of the study period, 100 patients had died. The 5-year OS for all patients was $72.0 \%$ (95\% CI, 66.0-76.7\%) (Table IV). 
Table III. Patient characteristics according to MAGEA2 and p53 expression levels for squamous cell carcinoma.

\begin{tabular}{|c|c|c|c|c|c|c|c|c|c|c|}
\hline \multirow[b]{3}{*}{ Patient characteristics } & \multicolumn{5}{|c|}{ MAGEA2 expression } & \multicolumn{5}{|c|}{ p53 expression } \\
\hline & \multicolumn{2}{|c|}{ Low } & \multicolumn{2}{|c|}{ High } & \multirow[b]{2}{*}{ P-value } & \multicolumn{2}{|c|}{ Wild-type } & \multicolumn{2}{|c|}{ Aberrant } & \multirow[b]{2}{*}{ P-value } \\
\hline & $\mathrm{N}$ & $\%$ & $\mathrm{~N}$ & $\%$ & & $\mathrm{~N}$ & $\%$ & $\mathrm{~N}$ & $\%$ & \\
\hline All patients & 30 & 34 & 59 & 66 & & 176 & 50 & 177 & 50 & \\
\hline Age (years) & & & & & 0.255 & & & & & 0.595 \\
\hline$<60$ & 8 & 47 & 9 & 53 & & 9 & 53 & 8 & 47 & \\
\hline$\geq 60$ & 22 & 31 & 50 & 69 & & 32 & 44 & 40 & 56 & \\
\hline Gender & & & & & 1.000 & & & & & 0.118 \\
\hline Female & 2 & 29 & 5 & 71 & & 1 & 14 & 6 & 86 & \\
\hline Male & 28 & 34 & 54 & 66 & & 40 & 49 & 42 & 51 & \\
\hline Smoking history & & & & & 0.479 & & & & & 0.498 \\
\hline Never-smoker & 4 & 44 & 5 & 56 & & 3 & 33 & 6 & 67 & \\
\hline Smoker & 26 & 32 & 54 & 68 & & 38 & 48 & 42 & 52 & \\
\hline pT factor & & & & & 0.046 & & & & & 0.479 \\
\hline pT1 & 4 & 17 & 20 & 83 & & 13 & 54 & 11 & 46 & \\
\hline pT2-4 & 26 & 40 & 39 & 60 & & 28 & 43 & 37 & 57 & \\
\hline $\mathrm{pN}$ factor & & & & & 0.630 & & & & & 0.819 \\
\hline pNO & 22 & 36 & 39 & 64 & & 29 & 48 & 32 & 52 & \\
\hline pN1-2 & 8 & 29 & 20 & 71 & & 12 & 43 & 16 & 57 & \\
\hline Pathologic stage & & & & & 0.070 & & & & & 0.590 \\
\hline Stage I & 13 & 29 & 32 & 71 & & 23 & 51 & 22 & 49 & \\
\hline Stage II & 13 & 52 & 12 & 48 & & 11 & 44 & 14 & 56 & \\
\hline Stage III & 4 & 21 & 15 & 79 & & 7 & 37 & 12 & 63 & \\
\hline Pleural invasion & & & & & 0.649 & & & & & 0.197 \\
\hline Absent & 17 & 32 & 37 & 68 & & 28 & 52 & 26 & 48 & \\
\hline Present & 13 & 37 & 22 & 63 & & 13 & 37 & 22 & 63 & \\
\hline p53 expression & & & & & 0.656 & & & & & \\
\hline Wild-type & 15 & 37 & 26 & 63 & & - & & - & & \\
\hline Aberrant & 15 & 31 & 33 & 69 & & - & & - & & \\
\hline
\end{tabular}

Significant P-values $(<0.05)$ are shown in bold. P-value was analyzed using the Pearson's $\chi^{2}$ test.

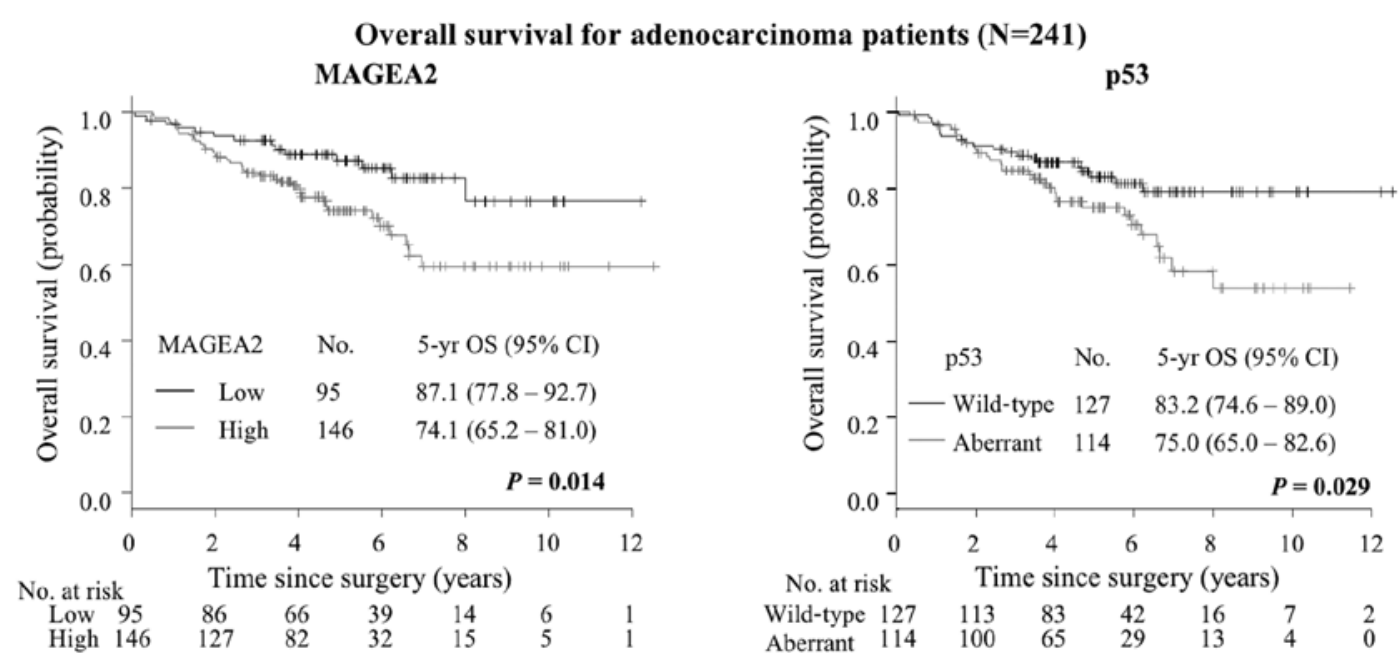

Figure 9. Expression of MAGEA2 and p53 protein and prognostic impact on lung cancers. Kaplan-Meier analysis of overall survival in patients with lung ADC according to MAGEA2, aberrant p53 expression level, and combination of MAGEA2 and p53 status. The 5-year overall survival (OS) rate was 87.1\% for patients with low-level MAGEA2 expression (Low-MAGEA2, $\mathrm{n}=95$ ), whereas $74.1 \%$ for patients with high-level MAGEA2 expression (High-MAGEA2, $\mathrm{n}=146)(\mathrm{P}=0.014)$. The 5 -year OS was $83.2 \%$ for patients with wild-type p53 expression $(\mathrm{n}=127)$, whereas $75.0 \%$ for patients with aberrant p53 expression $(\mathrm{n}=114)(\mathrm{P}=0.029)$. 
Table IV. Patient characteristics and univariate analyses of survival for all patients.

\begin{tabular}{|c|c|c|c|c|c|}
\hline \multirow[b]{2}{*}{ Factors } & \multicolumn{2}{|c|}{ Patients } & \multirow[b]{2}{*}{ 5-yr OS (\%) } & \multirow[b]{2}{*}{$95 \% \mathrm{CI}$} & \multirow[b]{2}{*}{ P-value } \\
\hline & No. & $\%$ & & & \\
\hline All patients & 353 & 100 & 72.0 & $66.0-76.7$ & \\
\hline Age (years) & & & & & 0.296 \\
\hline$<60$ & 122 & 35 & 74.7 & $65.3-81.9$ & \\
\hline$\geq 60$ & 231 & 65 & 70.8 & $64.0-76.5$ & \\
\hline Gender & & & & & 0.001 \\
\hline Female & 123 & 35 & 81.0 & $72.2-87.3$ & \\
\hline Male & 230 & 65 & 67.0 & $60.0-73.1$ & \\
\hline Smoking history & & & & & 0.023 \\
\hline Never-smoker & 119 & 34 & 80.0 & $71.1-86.4$ & \\
\hline Smoker & 234 & 66 & 67.8 & $60.8-73.8$ & \\
\hline Histological classification & & & & & $<0.001$ \\
\hline $\mathrm{ADC}$ & 241 & 68 & 79.4 & $73.2-84.3$ & \\
\hline $\mathrm{SqCC}$ & 89 & 25 & 54.2 & $42.4-64.6$ & \\
\hline $\mathrm{LCC}$ & 19 & 5 & 73.7 & $47.9-88.1$ & \\
\hline $\mathrm{SCC}$ & 4 & 1 & NA & NA & \\
\hline pT factor & & & & & $<0.001$ \\
\hline pT1 & 136 & 39 & 84.4 & $76.5-89.8$ & \\
\hline pT2-4 & 217 & 61 & 64.3 & $57.0-70.7$ & \\
\hline $\mathrm{pN}$ factor & & & & & $<0.001$ \\
\hline pNO & 265 & 75 & 81.2 & $75.4-85.7$ & \\
\hline pN1-2 & 88 & 25 & 43.9 & $32.4-54.8$ & \\
\hline \multicolumn{6}{|l|}{ Pathologic stage } \\
\hline Stage I & 228 & 65 & 85.5 & $79.6-89.7$ & $<0.001$ \\
\hline Stage II & 65 & 18 & 61.2 & $47.6-72.2$ & \\
\hline Stage III & 60 & 17 & 31.3 & $18.7-44.7$ & \\
\hline Pleural invasion & & & & & 0.014 \\
\hline Absent & 219 & 62 & 76.1 & $69.3-81.6$ & \\
\hline Present & 134 & 38 & 65.2 & $55.9-73.1$ & \\
\hline MAGEA2 expression & & & & & 0.022 \\
\hline Low & 132 & 37 & 78.9 & $70.4-85.2$ & \\
\hline High & 221 & 63 & 67.6 & $60.3-73.9$ & \\
\hline p53 expression & & & & & 0.013 \\
\hline Wild-type & 176 & 50 & 77.0 & $69.5-82.9$ & \\
\hline Aberrant & 177 & 50 & 66.9 & $58.8-73.8$ & \\
\hline MAGEA2/p53 combination & & & & & 0.008 \\
\hline Low/Wild-type & 96 & 27 & 85.5 & $76.2-91.4$ & \\
\hline Low/Aberrant & 36 & 10 & 61.4 & $42.5-75.7$ & \\
\hline High/Wild-type & 80 & 23 & 66.2 & $53.4-76.3$ & \\
\hline High/Aberrant & 141 & 40 & 68.4 & $59.2-75.9$ & \\
\hline MAGEA2 expression in wild-type p53 & & & & & 0.012 \\
\hline Low & 96 & 27 & 85.5 & $76.2-91.4$ & \\
\hline High & 80 & 23 & 66.2 & $53.4-76.3$ & \\
\hline MAGEA2 expression in aberrant type p53 & & & & & 0.662 \\
\hline Low & 36 & 10 & 61.4 & $42.5-75.7$ & \\
\hline High & 141 & 40 & 68.4 & $59.2-75.9$ & \\
\hline
\end{tabular}

ADC, adenocarcinoma; SqCC, squamous cell carcinoma; LCC, large cell carcinoma; SCC, Small cell carcinoma; CI, confidence interval. Significant P-values $(<0.05)$ are shown in bold. 


\section{Overall survival for squamous cell carcinoma patients $(\mathrm{N}=89)$}

MAGEA2

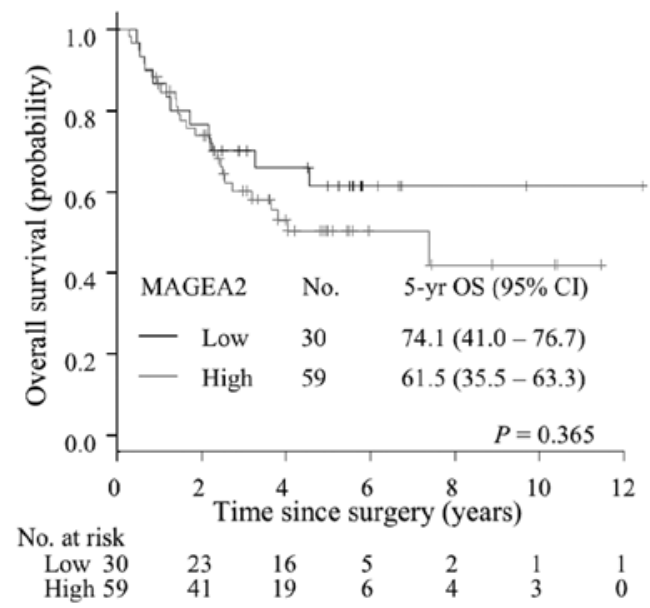

p53

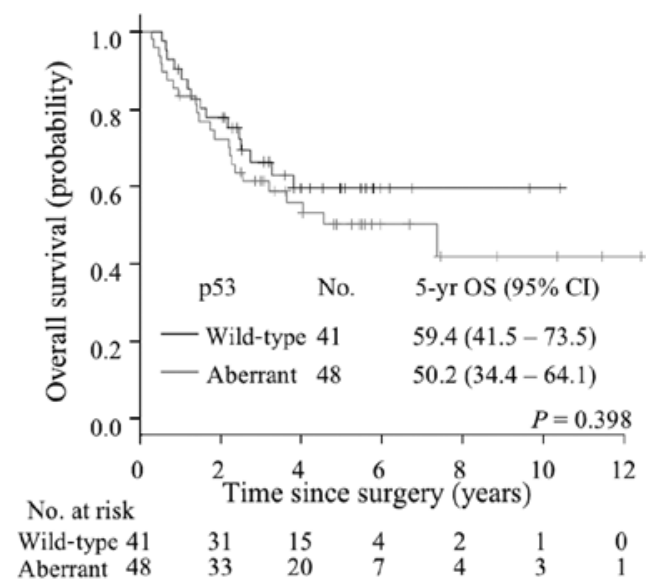

Figure 10. Expression of MAGEA2 and p53 protein and prognostic impact on lung cancers. Kaplan-Meier analysis of overall survival (OS) in squamous cell carcinoma patients according to MAGEA2 and aberrant p53 expression level and combination of MAGEA2 and aberrant p53. There were no significant differences between low expression of MAGEA2 and high expression of MAGEA2 ( $\mathrm{P}=0.365)$. There were no significant differences between wild-type p53 expression and aberrant $\mathrm{p} 53$ expression $(\mathrm{P}=0.398)$.

Kaplan-Meier method indicated that High-MAGEA2 was associated with increased risk of death (5-year OS, 78.9\% for low level vs. $67.6 \%$ for high level; $\mathrm{P}=0.022$, Fig. 8). Aberrant p53 was associated with increased risk of death (5-year OS, $77.0 \%$ for wild-type expression vs. $66.9 \%$ for aberrant expression; $\mathrm{P}=0.013$, Fig. 8). On univariate analysis for other clinicopathological factors, male gender $(\mathrm{P}=0.001)$, smoking history $(\mathrm{P}=0.023)$, patient with $\mathrm{SqCC}(\mathrm{P}<0.001)$, pT factor $(\mathrm{P}<0.001), \mathrm{pN}$ factor $(\mathrm{P}<0.001)$, pathological stage $(\mathrm{P}<0.001)$, pleural invasion $(\mathrm{P}=0.014)$ were correlated with worse $\mathrm{OS}$. Multivariate analyses were performed on the MAGEA2 expression and p53 status and these models were adjusted for the prognostic clinicopathologic factors, including gender, smoking status, pT stage (T2-4 vs. T1) and pN stage (N1, 2 vs. N0) and pleural invasion (Present vs. Absent). The final multivariate model confirmed pT stage (hazard ratio [HR] 1.79, 95\% CI 1.01-3.17; $\mathrm{P}=0.047$ ) and $\mathrm{pN}$ stage (HR 2.78, 95\% CI 1.83-4.21; $\mathrm{P}<0.001)$ remained independently associated with survival, but this was not observed with MAGEA2 expression and p53 status (Table V).

In patients with ADC, the 5-year OS was $79.4 \%$ (95\% CI, 73.2-84.3\%) (Table VI). Noteworthy, ADC patients with HighMAGEA2 revealed significantly shorter overall survival than those with Low-MAGEA2 (5-year OS, 87.1\% for low level vs. $74.1 \%$ for high level; $\mathrm{P}=0.014$ ) (Fig. 9), while SqCC patients did not show any difference although there was a tendency towards poorer prognosis with High-MAGEA2 $(\mathrm{P}=0.365)$ (Table VII, Fig. 10). We also performed univariate analysis to evaluate associations between prognosis and other factors in patients with ADC (Table VI). Among those parameters, advanced $\mathrm{pT}$ status $(\mathrm{P}=0.002)$, advanced $\mathrm{pN}$ status $(\mathrm{P}<0.001)$ and advanced pathological stage $(\mathrm{P}<0.001)$ were significantly associated with poor prognosis in ADC patients. Aberrant p53 expression was also significantly worse prognostic factor (5-year OS, $83.2 \%$ for wild-type expression vs. $75.0 \%$ for aberrant expression; $\mathrm{P}=0.029$ ) (Fig. 9). Next, we investigated MAGEA2 and aberrant p53 combinations. Among patients
Table V. Multivariate analysis of survival for all patients.

\begin{tabular}{lccc}
\hline Variable & HR & $95 \%$ CI & P-value \\
\hline $\begin{array}{l}\text { Gender } \\
\text { Male vs. Female }\end{array}$ & 1.68 & $0.96-2.94$ & 0.068 \\
$\begin{array}{l}\text { Smoking } \\
\text { Smoker vs. Never-smoker }\end{array}$ & 1.04 & $0.61-1.79$ & 0.881 \\
$\begin{array}{l}\text { T stage } \\
\text { T2-4 vs. T1 }\end{array}$ & 1.79 & $1.01-3.17$ & $\mathbf{0 . 0 4 7}$ \\
$\begin{array}{l}\text { N stage } \\
\text { N1,2 vs. N0 }\end{array}$ & 2.78 & $1.83-4.21$ & $<\mathbf{0 . 0 0 1}$ \\
$\begin{array}{l}\text { Pleural invasion } \\
\text { Present vs. Absent }\end{array}$ & 1.04 & $0.65-1.65$ & 0.883 \\
$\begin{array}{l}\text { MAGEA2 expression } \\
\text { High vs. Low }\end{array}$ & & & \\
$\begin{array}{l}\text { p53 expression } \\
\text { Aberrant vs. Wild-type }\end{array}$ & 1.55 & $0.97-2.49$ & 0.070 \\
\end{tabular}

HR, Hazard ratio; CI, confidence interval. Significant P-values $(<0.05)$ are shown in bold.

with wild-type p53 expression, High-MAGEA2 had worse prognosis than low MAGEA2 groups (5 year OS, 90.1\% vs. $72.1 \%, \mathrm{P}=0.037$, Fig. 11). On the other hand, among patients with aberrant type p53 expression, there were no significant differences in the High- and Low-MAGEA2 expression (5-year OS, $75.3 \%$ for low level vs. $75.1 \%$ for high level; $\mathrm{P}=0.756$ ) (Fig. 11). Multivariate analyses were performed for the MAGEA2 expression and p53 status and these models were adjusted for the prognostic clinicopathologic factors from univariate analysis, including gender, $\mathrm{pT}$ stage (T2-4 vs. T1) and pN stage (N1, 2 vs. N0). MAGEA2 
Table VI. Patient characteristics and univariate analyses of survival for adenocarcinoma.

\begin{tabular}{|c|c|c|c|c|c|}
\hline \multirow[b]{2}{*}{ Factors } & \multicolumn{2}{|c|}{ Patients } & \multirow[b]{2}{*}{$5-\mathrm{yr}$ OS (\%) } & \multirow[b]{2}{*}{$95 \% \mathrm{CI}$} & \multirow[b]{2}{*}{ P-value } \\
\hline & No. & $\%$ & & & \\
\hline All patients (ADC) & 241 & 100 & 79.4 & $73.2-84.3$ & \\
\hline Age (years) & & & & & 0.749 \\
\hline$<60$ & 96 & 40 & 80.0 & $69.6-87.2$ & \\
\hline$\geq 60$ & 145 & 60 & 79.1 & $70.7-85.4$ & \\
\hline Gender & & & & & 0.050 \\
\hline Female & 111 & 46 & 82.9 & $73.7-89.1$ & \\
\hline Male & 130 & 54 & 76.3 & $67.1-83.3$ & \\
\hline Smoking history & & & & & 0.115 \\
\hline Never-smoker & 105 & 44 & 84.1 & $74.8-90.1$ & \\
\hline Smoker & 136 & 56 & 75.7 & $66.6-82.6$ & \\
\hline pT factor & & & & & 0.002 \\
\hline pT1 & 103 & 43 & 87.9 & $79.1-93.2$ & \\
\hline pT2-4 & 138 & 57 & 73.0 & $63.9-80.2$ & \\
\hline $\mathrm{pN}$ factor & & & & & $<0.001$ \\
\hline $\mathrm{pN} 0$ & 188 & 78 & 86.4 & $80.1-91.0$ & \\
\hline $\mathrm{pN} 1-2$ & 53 & 22 & 53.8 & $40.5-69.6$ & \\
\hline Pathologic stage & & & & & $<0.001$ \\
\hline Stage I & 170 & 71 & 89.2 & $82.6-93.4$ & \\
\hline Stage II & 34 & 14 & 70.5 & $52.0-82.9$ & \\
\hline Stage III & 37 & 15 & 42.4 & $24.6-59.2$ & \\
\hline Pleural invasion & & & & & 0.291 \\
\hline Absent & 153 & 63 & 80.7 & $72.7-86.6$ & \\
\hline Present & 88 & 37 & 77.0 & $65.6-85.0$ & \\
\hline MAGEA2 expression & & & & & 0.014 \\
\hline Low & 95 & 39 & 87.1 & $77.8-92.7$ & \\
\hline High & 146 & 61 & 74.1 & $65.2-81.0$ & \\
\hline p53 expression & & & & & 0.029 \\
\hline Wild-type & 127 & 53 & 83.2 & $74.6-89.0$ & \\
\hline Aberrant & 114 & 47 & 75.0 & $65.0-82.6$ & \\
\hline MAGEA2/p53 combination & & & & & 0.043 \\
\hline Low/Wild-type & 78 & 33 & 90.1 & $80.1-95.2$ & \\
\hline Low/Aberrant & 17 & 7 & 75.3 & $46.8-89.9$ & \\
\hline High/Wild-type & 49 & 20 & 72.1 & $55.2-83.5$ & \\
\hline High/Aberrant & 97 & 40 & 75.1 & $63.9-83.2$ & \\
\hline MAGEA2 expression in wild-type p53 & & & & & 0.037 \\
\hline Low & 78 & 33 & 90.1 & $80.1-95.2$ & \\
\hline High & 49 & 20 & 72.1 & $55.2-83.5$ & \\
\hline MAGEA2 expression in aberrant type p53 & & & & & 0.756 \\
\hline Low & 17 & 7 & 75.3 & $46.8-89.9$ & \\
\hline High & 97 & 40 & 75.1 & $63.9-83.2$ & \\
\hline
\end{tabular}

ADC, adenocarcinoma; SqCC, squamous cell carcinoma; LCC, large cell carcinoma; SCC, Small cell carcinoma; CI, confidence interval. Significant P-values $(<0.05)$ are shown in bold. 
Table VII. Patient characteristics and univariate analyses of survival for squamous cell carcinoma.

\begin{tabular}{|c|c|c|c|c|c|}
\hline \multirow[b]{2}{*}{ Factors } & \multicolumn{2}{|c|}{ Patients } & \multirow[b]{2}{*}{$5-\mathrm{yr}$ OS (\%) } & \multirow[b]{2}{*}{$95 \% \mathrm{CI}$} & \multirow[b]{2}{*}{ P-value } \\
\hline & No. & $\%$ & & & \\
\hline All patients (SqCC) & 89 & 100 & 54.2 & $42.4-64.6$ & \\
\hline Age (years) & & & & & 0.891 \\
\hline$<60$ & 17 & 20 & 49.3 & $23.0-71.2$ & \\
\hline$\geq 60$ & 72 & 80 & 55.6 & $42.3-66.9$ & \\
\hline Gender & & & & & 0.545 \\
\hline Female & 7 & 8 & 66.7 & $19.5-90.4$ & \\
\hline Male & 82 & 92 & 53.3 & $41.0-64.1$ & \\
\hline Smoking history & & & & & 0.559 \\
\hline Never-smoker & 9 & 10 & 44.4 & $13.6-71.9$ & \\
\hline Smoker & 80 & 90 & 55.4 & $42.7-66.4$ & \\
\hline pT factor & & & & & 0.034 \\
\hline pT1 & 24 & 27 & 75.9 & $51.2-89.2$ & \\
\hline pT2-4 & 65 & 73 & 47.2 & $33.9-59.4$ & \\
\hline $\mathrm{pN}$ factor & & & & & $<0.001$ \\
\hline pNO & 61 & 69 & 69.9 & $55.8-80.3$ & \\
\hline $\mathrm{pN} 1-2$ & 28 & 31 & 22.0 & $8.3-39.9$ & \\
\hline Pathologic stage & & & & & $<0.001$ \\
\hline Stage I & 45 & 51 & 78.8 & $63.2-88.4$ & \\
\hline Stage II & 25 & 28 & 48.5 & $27.0-67.1$ & \\
\hline Stage III & 19 & 21 & 6.9 & $0.5-26.4$ & \\
\hline Pleural invasion & & & & & 0.008 \\
\hline Absent & 54 & 61 & 64.3 & $48.5-76.3$ & \\
\hline Present & 35 & 39 & 39.4 & $22.4-55.9$ & \\
\hline MAGEA2 expression & & & & & 0.365 \\
\hline Low & 30 & 34 & 74.1 & $41.0-76.7$ & \\
\hline High & 59 & 66 & 61.5 & $35.5-63.3$ & \\
\hline p53 expression & & & & & 0.398 \\
\hline Wild-type & 41 & 46 & 59.4 & $41.5-73.5$ & \\
\hline Aberrant & 48 & 54 & 50.2 & $34.4-64.1$ & \\
\hline MAGEA2/ p53 combination & & & & & 0.455 \\
\hline Low/Wild-type & 15 & 17 & 59.3 & $30.7-79.3$ & \\
\hline Low/Aberrant & 15 & 17 & 64.2 & $33.3-83.6$ & \\
\hline High/Wild-type & 26 & 29 & 59.2 & $35.1-76.9$ & \\
\hline High/Aberrant & 33 & 37 & 44.1 & $25.9-60.9$ & \\
\hline MAGEA2 expression in wild-type p53 & & & & & 0.821 \\
\hline Low & 15 & 17 & 59.3 & $30.7-79.3$ & \\
\hline High & 26 & 29 & 59.2 & $35.1-76.9$ & \\
\hline MAGEA2 expression in aberrant type p53 & & & & & 0.206 \\
\hline Low & 15 & 17 & 64.2 & $33.3-83.6$ & \\
\hline High & 33 & 37 & 44.1 & $25.9-60.9$ & \\
\hline
\end{tabular}

ADC, adenocarcinoma; SqCC, squamous cell carcinoma; LCC, large cell carcinoma; SCC, Small cell carcinoma; CI, confidence interval. Significant P-values $(<0.05)$ are shown in bold. 
Overall survival for adenocarcinoma patients in combination of MAGEA2 and p53 expression
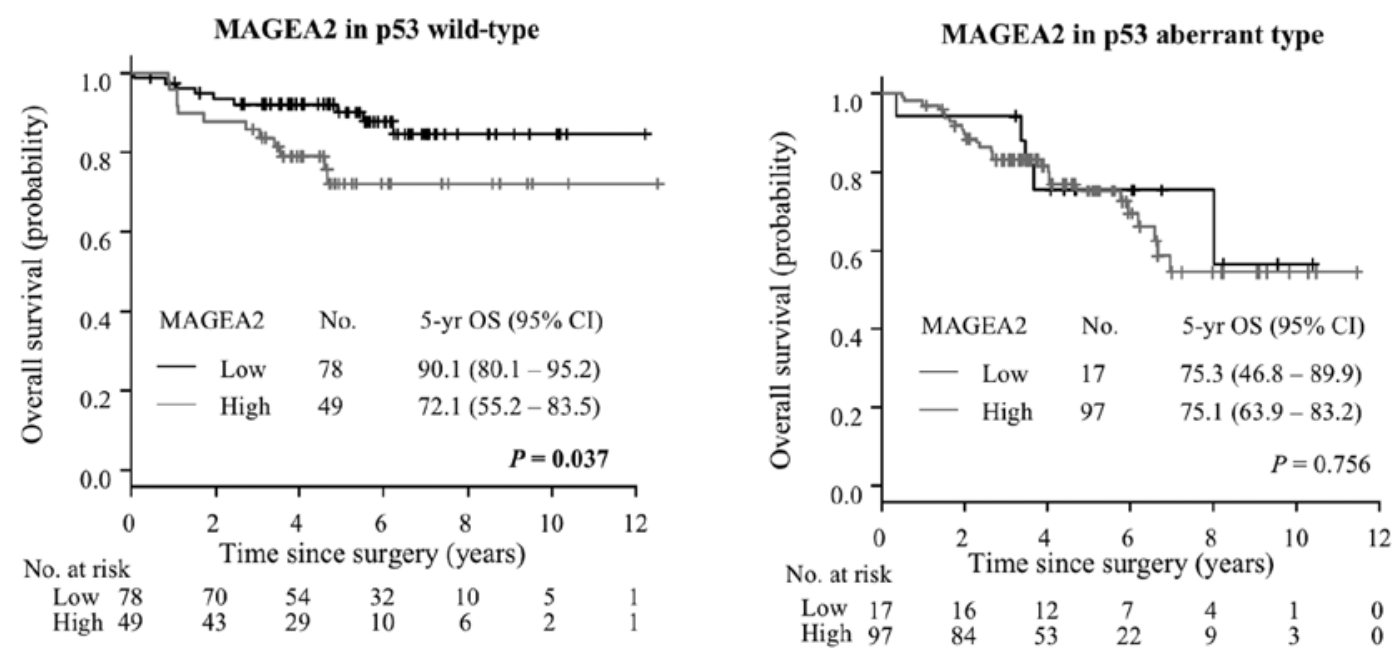

Figure 11. Combination of MAGEA2 and p53 protein expression and prognostic impact on LAC. Among the wild-type p53 patients, the 5-year OS was $90.1 \%$ for patients with Low-MAGEA2 $(n=78)$, whereas $72.1 \%$ for patients with High-MAGEA2 $(n=49)(P=0.037)$. Among the aberrant type p53 patients, the 5-year OS was $75.3 \%$ for patients with Low-MAGEA2 $(\mathrm{n}=17)$, whereas $75.1 \%$ for patients with High-MAGEA2 ( $\mathrm{n}=97)(\mathrm{P}=0.756)$.

Table VIII. Multivariate analysis of survival for adenocarcinoma.

\begin{tabular}{lccc}
\hline Variable & HR & $95 \%$ CI & P-value \\
\hline $\begin{array}{l}\text { Gender } \\
\text { (Male vs. Female) }\end{array}$ & 1.50 & $0.85-2.65$ & 0.160 \\
$\begin{array}{l}\text { T stage } \\
\text { (T2-4 vs. T1) }\end{array}$ & 1.73 & $0.88-3.38$ & 0.110 \\
$\begin{array}{l}\text { N stage } \\
\text { (T1,2 vs. N0) }\end{array}$ & 3.68 & $2.06-6.57$ & $<\mathbf{0 . 0 0 1}$ \\
$\begin{array}{l}\text { MAGEA2 expression } \\
\quad \text { High vs. Low) }\end{array}$ & 2.12 & $1.08-4.18$ & $\mathbf{0 . 0 3 0}$ \\
$\begin{array}{l}\text { p53 expression } \\
\text { (Aberrant vs. Wild-type) }\end{array}$ & 1.02 & $0.55-1.91$ & 0.945 \\
\hline
\end{tabular}

HR, Hazard ratio; CI, confidence interval. Significant P-values $(<0.05)$ are shown in bold.

expression was identified as an independent prognostic factor of lung ADC (HR 2.12, 95\% CI 1.08-4.18; $\mathrm{P}=0.030$ ) by multivariate analysis, as was $\mathrm{pN}$ status (HR $3.68,95 \% \mathrm{CI}$ 2.06-6.57; $\mathrm{P}<0.001$, Table VIII).

\section{Discussion}

MAGEA comprises of an 11-member subfamily of the broader family of MAGE proteins which are characterized by the presence of a MAGE-homology domain (11). The search for these genes as tumor-specific antigen has been active for many decades, however, the normal physiologic role of MAGEA proteins remains poorly understood and their contribution to cancer development is yet to be fully demonstrated (11). Only in recent years members of the MAGEA family have been shown to be implicated in various tumorigenic or tumor suppressive pathways. On one hand, MAGEA4, for example, promotes apoptosis and sensitization to chemotherapeutic agents, therefore functions as a tumor suppressor protein (40). MAGEA4 is also processed by a proteasome to generate a C-terminal fragment with pro-apoptotic activities, which increases the p53 protein level, and subsequent apoptosis (41). MAGEA genes have been shown to inhibit p53-dependent apoptosis in cancer cells, and contribute to tumor aggressiveness $(19,42)$. MAGEA protein blocked the association of p53 with its DNA binding surface of the p53 core domain, suppressing apoptosis in p53-dependent manner (19).

Herein, we showed for the first time that a high MAGEA2 expression level (High-MAGEA2) in patients with lung cancer, especially in ADC, is strongly associated with poor survival. In particular, patients with High-MAGEA2 have significantly poorer overall survival rate than those with Low-MAGEA2 in wild-type p53 tumors. In addition, HighMAGEA2 is an independent poor prognostic factor among lung ADC. In lung SqCC, however, there is no relation to p53 status and no prognostic difference between tumors with High- and Low-MAGEA2, although MAGEA2 expression is increased with tumor progression (pT factor). This prognostic significance indicates that p53/MAGEA2 interaction in cancer progression depends on histology and p53 status and suggests that therapies targeting MAGEA2 may improve patient survival for patients with ADC with p53 wild-type.

The p53 tumor-suppressor is a key transcription factor that controls cell proliferation, inducing growth arrest or apoptosis in response to different cellular stresses (43). p53 mutation is associated with invasiveness in ADC, suggesting this is a relatively late event during tumor development and plays an important role in the progression of the peripheral pulmonary ADC (24). However, little is known about the functional role of MAGE-A genes in tumorigenesis for $\mathrm{p} 53$ aberrant-type tumors. We found MAGEA2 expression to be significantly increased with aberrant $\mathrm{p} 53$ expression in ADC. In addition, downregulation of MAGEA2 in lung cancer cell 
with p53 mutation showed significant growth suppressive effect in vitro, although, unexpectedly, there is no difference in terms of prognosis between tumor with High-MAGEA2 and Low-MAGEA2 in patients with aberrant-type p53. We also examined the effect of MAGEA2 expression on the p53 downstream targets using lung cancer cell lines with p53 mutation. In p53 wild-type cancer cells, elimination of Mage-A expression in tumor-derived cells that retain functional p53 leads to increased recruitment of p53 to p53-responsive promoters and increases in p53-dependent transcription, cell cycle arrest, and cell death (19). To our surprise, we found that there was a significant decrease in expression of p53 downstream genes after suppression of MAGEA2. Taken together, these results indicate that MAGEA2 may contribute to the stability of p53 transcriptional activity in p53-mutated lung cancer cells, and the expression of MAGEA2 itself does not affect prognostic impact in p53 aberrant-type tumor, even though MAGEA2 is associated with tumor growth/survival. There is room for discussion about different functional roles of MAGEA2 in integrations between MAGEA2 and mutated-p53. Given our results in addition to the expression pattern of MAGEA2 reported in other studies, MAGEA2 is a promising molecular and immunogenic target even in lung cancer with p53 mutation and our finding helps understanding of the mechanisms that explains how MAGEA2 interacts with p53 activity according to p53 status, which also can be used to help develop new therapeutic strategy against lung cancer.

A limitation of this study is the efficacy of TMAs in reflecting gene expression in heterogeneity of lung cancer. TMA analysis is a promising technique in the evaluation of immunohistochemical markers in tumors and may be used as an alternative for whole sections. However, TMAs represent only a small portion of tissue collected and could be subject to sampling error. This should be considered a potential limitation of this finding and warrants further investigation with larger validate cohorts and using multiple TMA cores.

There have been no previous studies addressing the functional and prognostic role of MAGEA2 in lung cancer with regards to patients with resectable lung cancer. In the present study, we demonstrated that suppression of MAGEA2 in lung cancer cells significantly reduced the growth/survival of cells. Furthermore, MAGEA2 overexpression could be a useful index for patients with a high risk of poor prognosis in ADC patients. Although it still remains unclear as to how MAGEA2 is associated in tumorigenesis and p53 status, our study has shed some light on the biological function role of MAGEA2 in promoting lung cancer cell progression. Based on these results, specific inhibition of MAGEA2 can be a promising therapeutic agent for patients with lung cancer.

\section{Acknowledgements}

We are especially thankful to Dr Ming-Sound Tsao (Departments of Laboratory Medicine and Pathobiology, University of Toronto, Toronto, Ontario, Canada), for providing us with the lung cancer cell lines that we used in this study. We would like to thank Ms. Alexandria Grindlay and Ms. Judy McConnell (Toronto General Hospital) for supporting the research work. H.U. received a research scholarship from the Joseph M. West Family Memorial Fund.

\section{References}

1. Siegel RL, Miller KD and Jemal A: Cancer statistics, 2016. CA Cancer J Clin 66: 7-30, 2016.

2. Aberle DR, Adams AM, Berg CD, Black WC, Clapp JD, Fagerstrom RM, Gareen IF, Gatsonis C, Marcus PM and Sicks JD; National Lung Screening Trial Research Team: Reduced lung-cancer mortality with low-dose computed tomographic screening. N Engl J Med 365: 395-409, 2011.

3. Ujiie H, Kadota K, Chaft JE, Buitrago D, Sima CS, Lee MC, Huang J, Travis WD, Rizk NP, Rudin CM, et al: Solid predominant histologic subtype in resected stage I lung adenocarcinoma is an independent predictor of early, extrathoracic, multisite recurrence and of poor postrecurrence survival. J Clin Oncol 33: 2877-2884, 2015.

4. National Cancer Institute: Surveillance, Epidemiology, and End Results Program. Cancer Stat Facts, Lung and Bronchus Cancer. $\mathrm{http} / / /$ seer.cancer.gov/statfacts/html/lungb.html.

5. Ujiie H, Tomida M, Akiyama H, Nakajima Y, Okada D, Yoshino N, Takiguchi Y and Tanzawa H: Serum hepatocyte growth factor and interleukin-6 are effective prognostic markers for non-small cell lung cancer. Anticancer Res 32: 3251-3258, 2012.

6. Ujiie H, Lee D, Kato T and Yasufuku K: Gene Signature. In: Molecular Targeted Therapy of Lung Cancer. Takiguchi Y (ed). Springer Singapore, Singapore, pp279-292, 2017.

7. Nakajima T, Zamel R, Anayama T, Kimura H, Yoshino I, Keshavjee S and Yasufuku K: Ribonucleic acid microarray analysis from lymph node samples obtained by endobronchial ultrasonography-guided transbronchial needle aspiration. Ann Thorac Surg 94: 2097-2101, 2012.

8. Kato T, Wada H, Patel P, Hu HP, Lee D, Ujiie H, Hirohashi K, Nakajima T, Sato M, Kaji M, et al: Overexpression of KIF23 predicts clinical outcome in primary lung cancer patients. Lung Cancer 92: 53-61, 2016.

9. van der Bruggen P, Traversari C, Chomez P, Lurquin C, De Plaen E, Van den Eynde B, Knuth A and Boon T: A gene encoding an antigen recognized by cytolytic $\mathrm{T}$ lymphocytes on a human melanoma. Science 254: 1643-1647, 1991.

10. Chomez P, De Backer O, Bertrand M, De Plaen E, Boon T and Lucas S: An overview of the MAGE gene family with the identification of all human members of the family. Cancer Res 61: 5544-5551, 2001.

11. Simpson AJ, Caballero OL, Jungbluth A, Chen YT and Old LJ: Cancer/testis antigens, gametogenesis and cancer. Nat Rev Cancer 5: 615-625, 2005.

12. Weynants P, Lethé B, Brasseur F, Marchand M and Boon T: Expression of mage genes by non-small-cell lung carcinomas. Int J Cancer 56: 826-829, 1994.

13. Mecklenburg I, Stratakis DF, Huber RM, Häussinger K, Morresi-Hauf A, Riethmüller G and Kufer P: Detection of melanoma antigen-A expression in sputum and bronchial lavage fluid of patients with lung cancer. Chest 125 (Suppl): S164-S166, 2004.

14. Jheon S, Hyun DS, Lee SC, Yoon GS, Jeon CH, Park JW, Park CK, Jung MH, Lee KD and Chang HK: Lung cancer detection by a RT-nested PCR using MAGE A1 - 6 common primers. Lung Cancer 43: 29-37, 2004.

15. Hutchinson TP: Patterns of melanoma antigen-A expression in lung cancer patients. Chest 128: 1069-1070, 2005.

16. Mecklenburg I, Sienel W, Schmid S, Passlick B and Kufer P: A threshold of systemic MAGE-A gene expression predicting survival in resected non-small cell lung cancer. Clin Cancer Res 23: 1213-1219, 2017.

17. Vansteenkiste JF, Cho BC, Vanakesa T, De Pas T, Zielinski M, Kim MS, Jassem J, Yoshimura M, Dahabreh J, Nakayama H, et al: Efficacy of the MAGE-A3 cancer immunotherapeutic as adjuvant therapy in patients with resected MAGE-A3-positive non-small-cell lung cancer (MAGRIT): A randomised, doubleblind, placebo-controlled, phase 3 trial. Lancet Oncol 17: 822-835, 2016.

18. Pujol JL, Vansteenkiste JF, De Pas TM, Atanackovic D, Reck M, Thomeer M, Douillard JY, Fasola G, Potter V, Taylor P, et al: Safety and immunogenicity of MAGE-A3 cancer immunotherapeutic with or without adjuvant chemotherapy in patients with resected stage IB to III MAGE-A3-positive non-small-cell lung cancer. J Thorac Oncol 10: 1458-1467, 2015.

19. Marcar L, Maclaine NJ, Hupp TR and Meek DW: Mage-A cancer/testis antigens inhibit p53 function by blocking its interaction with chromatin. Cancer Res 70: 10362-10370, 2010. 
20. Monte M, Simonatto M, Peche LY, Bublik DR, Gobessi S, Pierotti MA, Rodolfo M and Schneider C: MAGE-A tumor antigens target p53 transactivation function through histone deacetylase recruitment and confer resistance to chemotherapeutic agents. Proc Natl Acad Sci USA 103: 11160-11165, 2006.

21. Peche LY, Scolz M, Ladelfa MF, Monte M and Schneider C MageA2 restrains cellular senescence by targeting the function of PMLIV/p53 axis at the PML-NBs. Cell Death Differ 19: 926-936, 2012

22. Gazzeri S, Brambilla E, Caron de Fromentel C, Gouyer V, Moro D, Perron P, Berger F and Brambilla C: p53 genetic abnormalities and myc activation in human lung carcinoma. Int $\mathrm{J}$ Cancer 58: 24-32, 1994.

23. Ding L, Getz G, Wheeler DA, Mardis ER, McLellan MD, Cibulskis K, Sougnez C, Greulich H, Muzny DM, Morgan MB, et al: Somatic mutations affect key pathways in lung adenocarcinoma. Nature 455: 1069-1075, 2008

24. Yoo SB, Chung JH, Lee HJ, Lee CT, Jheon S and Sung SW: Epidermal growth factor receptor mutation and p53 overexpression during the multistage progression of small adenocarcinoma of the lung. J Thorac Oncol 5: 964-969, 2010.

25. Wu H, Gao L, Li F, Song F, Yang X and Kasabov N: Identifying overlapping mutated driver pathways by constructing gene networks in cancer. BMC Bioinformatics 16 (Suppl 5): S3, 2015.

26. Kato T, Daigo Y, Aragaki M, Ishikawa K, Sato M and Kaji M: Overexpression of CDC20 predicts poor prognosis in primary non-small cell lung cancer patients. J Surg Oncol 106: 423-430, 2012.

27. Kato T, Daigo Y, Aragaki M, Ishikawa K, Sato M and Kaji M: Overexpression of KIAA0101 predicts poor prognosis in primary lung cancer patients. Lung Cancer 75: 110-118, 2012.

28. Kato T, Daigo Y, Aragaki M, Ishikawa K, Sato M, Kondo S and Kaji M: Overexpression of MAD2 predicts clinical outcome in primary lung cancer patients. Lung Cancer 74: 124-131, 2011

29. Travis WD, Brambilla E, Burke AP, Marx A and Nicholson AG: WHO Classification of Tumours of the Lung, Pleura, Thymus and Heart. Fourth edition. In: WHO Classification of Tumours, Volume 7. WHO Publications Center, Albany, NY, 2015.

30. Edge SB and Compton CC: The American Joint Committee on Cancer: the 7th edition of the AJCC cancer staging manual and the future of TNM. Ann Surg Oncol 17: 1471-1474, 2010.

31. Nakajima T, Anayama T, Koike T, Waddell T, Keshavjee $S$ Kimura H, Yoshino I and Yasufuku K: Simultaneous isolation of total RNA, DNA, and protein using samples obtained by EBUSTBNA. J Bronchology Interv Pulmonol 18: 301-305, 2011.

32. ImageScope viewing software. Leica Biosystem Imaging, INC. http://www.leicabiosystems.com/pathology-imaging/aperioepathology/integrate/imagescope/.
33. Rizzardi AE, Johnson AT, Vogel RI, Pambuccian SE, Henriksen J, Skubitz AP, Metzger GJ and Schmechel SC: Quantitative comparison of immunohistochemical staining measured by digital image analysis versus pathologist visual scoring. Diagn Pathol 7: 42, 2012.

34. Nagashio R, Sato Y, Jiang SX, Ryuge S, Kodera Y, Maeda T and Nakajima T: Detection of tumor-specific autoantibodies in sera of patients with lung cancer. Lung Cancer 62: 364-373, 2008

35. Nagashio R, Sato Y, Matsumoto T, Kageyama T, Satoh Y, Shinichiro R, Masuda N, Goshima N, Jiang SX and Okayasu I: Expression of RACK1 is a novel biomarker in pulmonary adenocarcinomas. Lung Cancer 69: 54-59, 2010.

36. Ujiie H, Kadota K, Nitadori JI, Aerts JG, Woo KM, Sima CS, Travis WD, Jones DR, Krug LM and Adusumilli PS: The tumoral and stromal immune microenvironment in malignant pleural mesothelioma: A comprehensive analysis reveals prognostic immune markers. Oncoimmunology 4: e1009285, 2015.

37. Cha YJ, Kim HR, Lee CY, Cho BC and Shim HS: Clinicopathological and prognostic significance of programmed cell death ligand-1 expression in lung adenocarcinoma and its relationship with p53 status. Lung Cancer 97: 73-80, 2016.

38. Shim HS, Kenudson M, Zheng Z, Liebers M, Cha YJ, Hoang Ho Q, Onozato M, Phi Le L, Heist RS and Iafrate AJ: Unique genetic and survival characteristics of invasive mucinous adenocarcinoma of the lung. J Thorac Oncol 10: 1156-1162, 2015

39. Brattström D, Bergqvist M, Lamberg K, Kraaz W, Scheibenflug L, Gustafsson G, Inganäs M, Wagenius $\mathrm{G}$ and Brodin O: Complete sequence of p53 gene in 20 patients with lung cancer: Comparison with chemosensitivity and immunohistochemistry. Med Oncol 15: 255-261, 1998.

40. Peikert T, Specks U, Farver C, Erzurum SC and Comhair SA: Melanoma antigen A4 is expressed in non-small cell lung cancers and promotes apoptosis. Cancer Res 66: 4693-4700, 2006.

41. Sakurai T, Itoh K, Higashitsuji H, Nagao T, Nonoguchi K, Chiba T and Fujita J: A cleaved form of MAGE-A4 binds to Miz-1 and induces apoptosis in human cells. J Biol Chem 279: 15505-15514, 2004.

42. Yang B, O'Herrin SM, Wu J, Reagan-Shaw S, Ma Y, Bhat KM, Gravekamp C, Setaluri V, Peters N, Hoffmann FM, et al: MAGE-A, mMage-b, and MAGE-C proteins form complexes with KAP1 and suppress p53-dependent apoptosis in MAGEpositive cell lines. Cancer Res 67: 9954-9962, 2007.

43. Harris SL and Levine AJ: The p53 pathway: Positive and negative feedback loops. Oncogene 24: 2899-2908, 2005. 